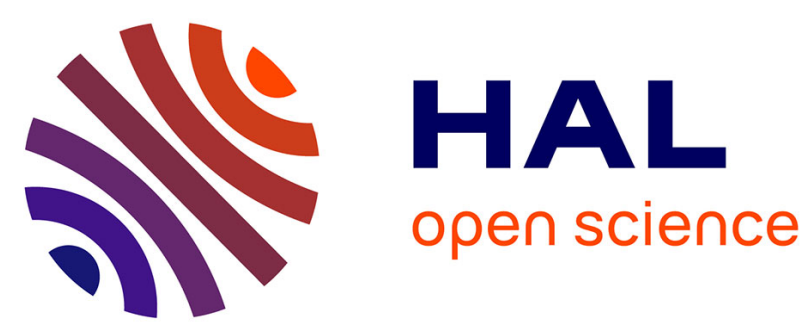

\title{
A Glutathione Reductase-Catalyzed Cascade of Redox Reactions to Bioactivate Potent Antimalarial 1,4-Naphthoquinones - A New Strategy to Combat Malarial Parasites
}

Tobias Müller, Laure Johann, Beate Jannack, Margit Brückner, Don Antoine Lanfranchi, Holger Bauer, Cecilia Sanchez, Vanessa Yardley, Christiane Deregnaucourt, Joseph Schrével, et al.

\section{- To cite this version:}

Tobias Müller, Laure Johann, Beate Jannack, Margit Brückner, Don Antoine Lanfranchi, et al.. A Glutathione Reductase-Catalyzed Cascade of Redox Reactions to Bioactivate Potent Antimalarial 1,4Naphthoquinones - A New Strategy to Combat Malarial Parasites. Journal of the American Chemical Society, 2011, 133 (30), pp.11557-11571. 10.1021/ja201729z . hal-03406270

\author{
HAL Id: hal-03406270 \\ https://hal.science/hal-03406270
}

Submitted on 27 Oct 2021

HAL is a multi-disciplinary open access archive for the deposit and dissemination of scientific research documents, whether they are published or not. The documents may come from teaching and research institutions in France or abroad, or from public or private research centers.
L'archive ouverte pluridisciplinaire HAL, est destinée au dépôt et à la diffusion de documents scientifiques de niveau recherche, publiés ou non, émanant des établissements d'enseignement et de recherche français ou étrangers, des laboratoires publics ou privés. 


\title{
A Glutathione Reductase-Catalyzed Cascade of Redox Reactions to Bioactivate Potent Antimalarial 1,4-Naphthoquinones - A New Strategy to Combat Malarial Parasites ${ }^{\dagger}$
}

\author{
Tobias Müller, ${ }^{\ddagger, \#}$ Laure Johann, ${ }^{\ddagger, \S, \# ~ B e a t e ~ J a n n a c k, ~}{ }^{\ddagger}$ Margit Brückner, ${ }^{\ddagger}$ Don \\ Antoine Lanfranchi, ${ }^{\S}$ Holger Bauer, ${ }^{\ddagger}$ Cecilia Sanchez, ${ }^{\circledR}$ Vanessa Yardley, ${ }^{\perp}$ \\ Christiane Deregnaucourt, ${ }^{\circ}$ Joseph Schrével, ${ }^{\circ}$ Michael Lanzer, "R. Heiner \\ Schirmer, ${ }^{\ddagger}$ Elisabeth Davioud-Charvet ${ }^{\ddagger, \S, *}$
}

Contribution from the Biochemie-Zentrum der Universität Heidelberg, Im Neuenheimer Feld 328, D-69120 Heidelberg, Germany, European School of Chemistry, Polymers and Materials (ECPM), University of Strasbourg, UMR CNRS 7509, 25, rue Becquerel, F-67087 Strasbourg, France, Department of Infectiology, University of Heidelberg, Im Neuenheimer Feld 324, 69120 Heidelberg, Germany, Department of Infections and Tropical Diseases, London School of Hygiene \& Tropical Medicine, Keppel Street, London WC1E 7HT, United Kingdom, and Muséum National d'Histoire Naturelle, FRE 3206 CNRS, BP 52, 61 rue Buffon, 75231 Paris cedex 05, France

\section{E-mail: elisabeth.davioud@ unistra.fr}

Running title: Antimalarial Redox-Active 1,4-Naphthoquinones

\begin{abstract}
Our work on targeting redox equilibria of malarial parasites propagating in red blood cells has led to the selection of six 1,4-naphthoquinones which are active at nanomolar concentrations against the human pathogen Plasmodium falciparum in culture and against Plasmodium berghei in infected mice. With respect to safety, the compounds do not trigger hemolysis or other signs of toxicity in mice. Concerning the antimalarial mode of action, we propose that the lead benzyl naphthoquinones are initially oxidized at the benzylic chain to benzoyl naphthoquinones in a heme-catalyzed reaction within the digestive acidic vesicles of the parasite. The major putative benzoyl metabolites were then found to function as redox cyclers: (i) in their oxidized form, the benzoyl metabolites are reduced by NADPH in glutathione reductase-catalyzed reactions within the cytosols of infected red blood cells; (ii) in their reduced forms, these benzoyl metabolites can convert methemoglobin, the major nutrient of the parasite, to indigestible hemoglobin. Studies on a fluorinated suicide-substrate indicate as well that the glutathione reductase-catalyzed bioactivation of naphthoquinones is essential for the observed antimalarial activity. In conclusion, the antimalarial naphthoquinones are suggested to perturb the major redox equilibria of the targeted infected red blood cells, which might be removed by macrophages. This results in development arrest and death of the malaria parasite at the trophozoite stage.
\end{abstract}

$\uparrow$ Abbreviations: abs, absolute; BuLi, butyllithium; CAN, cerium(IV) ammonium nitrate; DAST, diethylaminosulfur trifluoride; DMSO, dimethyl sulfoxide; EA, elemental analysis; EI MS, electron impact mass spectrometry; FAB MS, fast atom bombardment mass spectrometry; fluoroM5, 6-[2'-(3'-fluoromethyl)-1',4'-naphthoquinolyl]hexanoic acid; GR, glutathione reductase; GSH, reduced glutathione, GSSG, glutathione disulfide; HMS, hexose monophosphate shunt; IR, infraredspectroscopy; LDA, lithium diisopropyl amide, MeOH, methanol; m.p., melting point; NBA, nitrobenzyl alcohol (matrix); NQ,

\footnotetext{
$\$$ Biochemie-Zentrum der Universität Heidelberg,

${ }^{\S}$ European School of Chemistry, Polymers and Materials, University of Strasbourg,

I Department of Infectiology, University of Heidelberg,

${ }^{\perp}$ London School of Hygiene \& Tropical Medicine,

O Muséum National d'Histoire Naturelle, Paris.

\# T. M. and L. J. contributed equally as primo et aequo loco authors.
} 
naphthoquinone; PE, petroleum ether; rt, room temperature; sat, saturated; THF, tetrahydrofurane; TLC, thin layer chromatography; TMS, tetramethylsilane; UV, ultra-violet.

\section{Introduction}

Malaria is a major tropical parasitic disease affecting 500 million people worldwide and causing the death of one to two million people per year, mostly children in Africa. Plasmodium is the causative agent of malaria; the most dangerous species is $P$. falciparum which is responsible for malaria complications such as cerebral malaria or severe anemia. Multi-drugresistance of Plasmodium towards broadly-used antimalarial drugs (e.g. chloroquine, sulphadoxinepyrimethamine) has spread all over the world in the last five decades. Resistance to artemisinin has now emerged. ${ }^{1}$ Therefore, new drugs are urgently needed, especially in poor countries. These drugs must be cheap and easy to synthesize, and exhibit mechanism(s) of action that counteract parasite resistance to drugs in use.

The malarial parasite $P$. falciparum digests a large amount of its host cell hemoglobin during the intraerythrocytic cycle as a source of essential nutrients (Figure 1). ${ }^{2}$ Hemoglobin digestion takes place in acidic vesicles and in the food vacuole of the parasite; ${ }^{3 a}$ this leads to the formation of iron(III) ferriprotoporphyrin $\left(\mathrm{FPIX}\left(\mathrm{Fe}^{\mathrm{III}}\right)\right.$ or $\mathrm{FPIX}-\mathrm{OH}\left(\mathrm{Fe}^{\mathrm{III}}\right)$ or hematin) as a toxic by-product to the parasite. ${ }^{3 \mathrm{~b}-\mathrm{e}}$ In the course of this prooxidative process the parasite is exposed to elevated fluxes of reactive oxygen species.

Figure 1. Heme Detoxification Pathways in the Intraerythrocytic Cycle of $P$. falciparum and Redox Homeostasis in $P$. falciparum-Infected Red Blood Cell. ${ }^{a}$

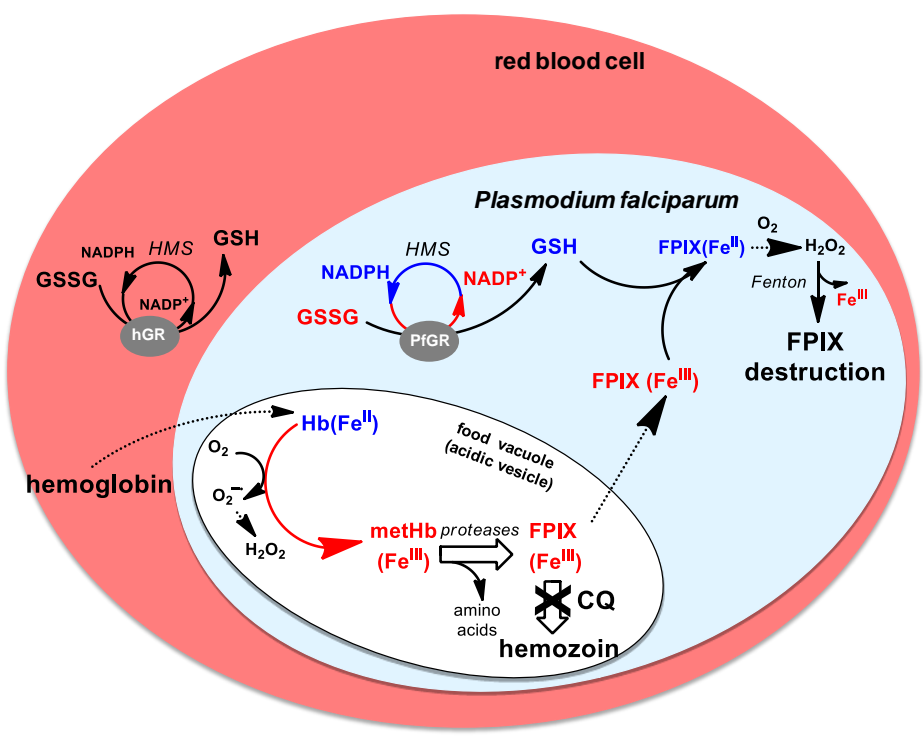

${ }^{a}$ HMS, hexose monophosphate shunt. CQ, chloroquine is an inhibitor of hemozoin formation (designated by the black X).
The parasite evades the toxicity of the released heme by expressing at least two major detoxification pathways, the hemozoin formation in the food vacuole and an efficient thiol network in the cytosol. First, $\operatorname{FPIX}\left(\mathrm{Fe}^{\mathrm{III}}\right)$ is polymerized forming crystals of hemozoin or malaria pigment. ${ }^{4}$ Secondly, $\operatorname{FPIX}\left(\mathrm{Fe}^{\mathrm{III}}\right)$ is thought to undergo rapid peroxidative decomposition by reacting with $\mathrm{H}_{2} \mathrm{O}_{2}$, mainly in the food vacuole, i.e. at $\mathrm{pH} 5.2$ where autooxidation of hemoglobin $\left(\mathrm{Fe}^{\mathrm{II}}\right)(\mathrm{Hb})$ takes place. ${ }^{5}$ Degradation of heme might also be significant in the cytosol via Fenton reactions, in the presence of glutathione ${ }^{6}$ and molecular oxygen following the generation of $\operatorname{FPIX}\left(\mathrm{Fe}^{\mathrm{II}}\right)$. A number of antimalarial drugs such as chloroquine (CQ) and related 4-aminoquinolines, quinine, as well as the phenothiazine methylene blue (MB), are known to act as inhibitors of hemozoin formation due to their binding to noncrystalline heme. ${ }^{3}$ In sensitive parasites, CQ prevents heme detoxification resulting in free heme accumulation, in the food vacuole and in membranes, which in concert with oxygen species is thought to catalyze oxidation reactions and protein damage causing parasite death. ${ }^{7}$ Malarial parasites digest methemoglobin $\left(\mathrm{Fe}^{\mathrm{III}}\right)$ (metHb) faster than $\mathrm{Hb}\left(\mathrm{Fe}^{\mathrm{II}}\right){ }^{8}$ Therefore, the reduction of metHb can be used to slow down the parasite's metHb digestion rate. Since $\operatorname{FPIX}\left(\mathrm{Fe}^{\mathrm{II}}\right)$ is also an inhibitor of heme polymerization, ${ }^{9}$ redox-active compounds displaying the ability to reduce $\operatorname{FPIX}\left(\mathrm{Fe}^{\mathrm{III}}\right)$ to $\mathrm{FPIX}\left(\mathrm{Fe}^{\mathrm{II}}\right)$ can lead to the decrease of hemozoin formation and increased oxidative stress in infected-red blood cells to. Both events would contribute to the arrest of trophozoite development. Thus, agents with redox-cycling activity able to generate $\mathrm{Fe}^{\mathrm{II}}$ from $\mathrm{Fe}^{\mathrm{III}}$ states either at the hemoglobin or at the heme levels might act as putative antimalarial agents.

A most important antioxidative system consists of thiols which are regenerated by NADPH-dependent disulfide reductases; these include the glutathione reductases (GR, E.C. 1.8.1.7) from the parasite $P$. falciparum and of human erythrocytes. Both enzymes are targets of antimalarial drugs. ${ }^{10}$ These enzymes are essential proteins for the survival of the malarial parasite infecting red blood cells. They maintain the redox equilibrium in the cytosol by catalyzing the physiological reaction, i.e. the reduction of glutathione disulfide (GSSG) to its thiol form glutathione (GSH): $\mathrm{NADPH}+\mathrm{H}^{+}+\mathrm{GSSG} \rightarrow \mathrm{NADP}^{+}+2 \mathrm{GSH}$, in particular during the intensive production of reactive oxygen species resulting from hemoglobin digestion.

Different types of inhibitors (reversible, irreversible) were designed in the 1,4-naphthoquinone series $^{11,12}$ to evaluate the impact of each inhibition mode on the propagation of the parasites. They ranged from 
uncompetitive or catalytic inhibitors (equation 1, Scheme 1), ${ }^{11 \mathrm{a}, \mathrm{c}}$ to fluorine-based suicide-substrates, ${ }^{11 \mathrm{~b}}$ and their related prodrugs. ${ }^{12}$ Considering the different inhibitor types the most potent antimalarial effects were indeed observed for redox-cyclers acting as subversive substrates (equation 2 and Scheme 1). These compounds are reduced via 1 or 2 electron(s)-transfer and regenerated in the presence of molecular oxygen, with the concomitant production of superoxide anion radicals.

Scheme 1. Redox-Active 1,4-Naphthoquinones as Subversive Substrates of NADPH-Dependent Disulfide Reductases.

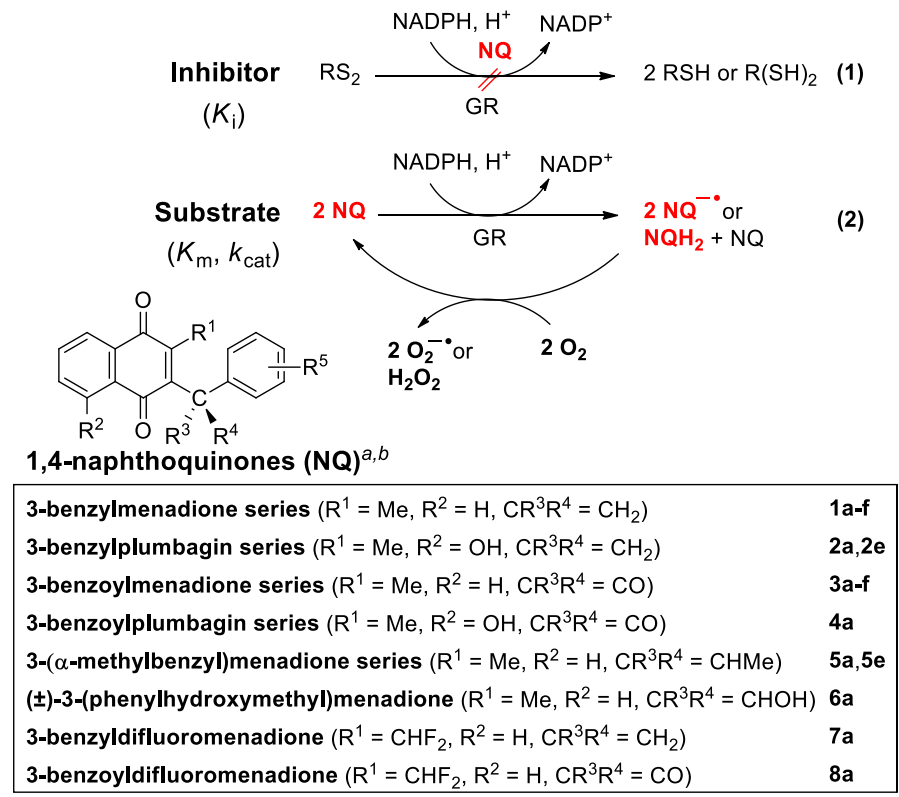

${ }^{a}$ Key structures are shown in Figure $3 ;{ }^{b} \mathrm{R}^{5}$ is the series variable.

Starting from an identified lead antimalarial 3benzylmenadione 1a (Scheme 1), we report here how we prepared the 3-benzylmenadione analogues 1, 2, 5, 7 (benzylNQ), and 9 (azaNQ) and oriented the investigations to the oxidative metabolism of the potent antimalarial 3-(substituted-benzyl)menadiones 1, 2 (see general structures in Scheme 1). Since the infected erythrocytes are the target of the lead compound, we hypothesized that the benzylNQ 1a might be subjected to heme-catalyzed oxidation reactions under oxidative conditions in the acidic vesicles or in the food vacuole as part of the drug bioactivation mechanism (Scheme 2 and Figure 2). Based on this hypothesis, we prepared the putative metabolites oxidized in the benzyl position, ${ }^{13}$ i.e. a menadione (or plumbagin, i.e. 5hydroxymenadione) substituted by a 3-benzoyl-chain (benzoylNQ) 3, 4 and the related "benzhydrol" $6 \mathbf{a}$ (Scheme 1). We also synthesized a series of 3-( $\alpha-$ methylbenzyl)NQ series 5a,5e (Scheme 1) as metabolically-resistant derivatives since oxidation might be hampered. To correlate the antimalarial effects of 1a with the redox system, we envisioned that the
GR-reduced NQ might also play a role both in the hemoglobin redox status and the drug bioactivation process (Scheme 2 and Figure 2). Therefore, as a link between the thiol network and the heme metabolism we showed that the metabolites I, the benzoylNQ, might subsequently be reduced by GR in the cytosols (Scheme 2). Taking into account the putative redox-active behavior of the benzoylNQ metabolites, we then investigated if, in their reduced form, they could convert metHb to $\mathrm{Hb}$ in vitro, as $\mathrm{MB}$ and menadione do so in vivo. ${ }^{14}$ As an expected outcome, we observed an inhibition of hemozoin formation and the arrest of trophozoite development in experiments with synchronized parasites in vitro (Figure 2).

Scheme 2. Putative Redox Cascade Reactions Accounting for the Observed Antimalarial Activity of 3Benzylmenadione Derivatives.

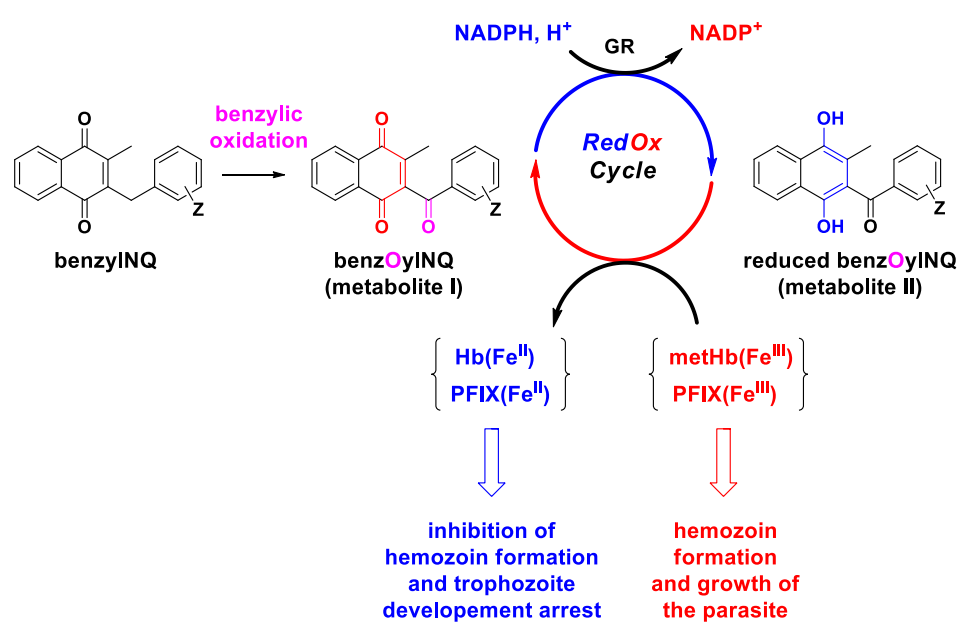

Finally, to offer evidence for the concept that the GR-catalyzed bioactivation step is essential for the observed antimalarial activity of the 3benzylmenadione series, the synthesis of a difluoromethyl analogue (7a, Scheme 1) of the lead 3benzylmenadione 1a was designed to generate in situ (i.e. in the parasite) the corresponding 3-benzoyldifluoromenadione metabolite. This compound, the 3benzoylmenadione 8a, when synthesized (Scheme 1), was shown to act as a potent suicide-substrate of isolated GRs. Hence, the GR inactivation by the bioreducible alkylating NQ may be correlated with the abolishment of the antimalarial activity of the parent difluorinated benzylNQ 7a. Our data support the essential role of an active GR, within a cascade of redox reactions to bioactivate potent antimalarial 1,4naphthoquinones. This GR-dependent drug bioactivation process combined to the prodrug effect specifically present in Plasmodium via the hematincatalyzed oxidation reactions represents a new strategy to combat malarial parasites. 
Figure 2. Putative Model for Lead 1,4-Naphthoquinone Bioactivation Affecting Redox Homeostasis in P. falciparum Through a Cascade of Redox Reactions Accounting for the Observed Antimalarial Activity of 3-Benzylmenadione Derivatives. $^{a}$

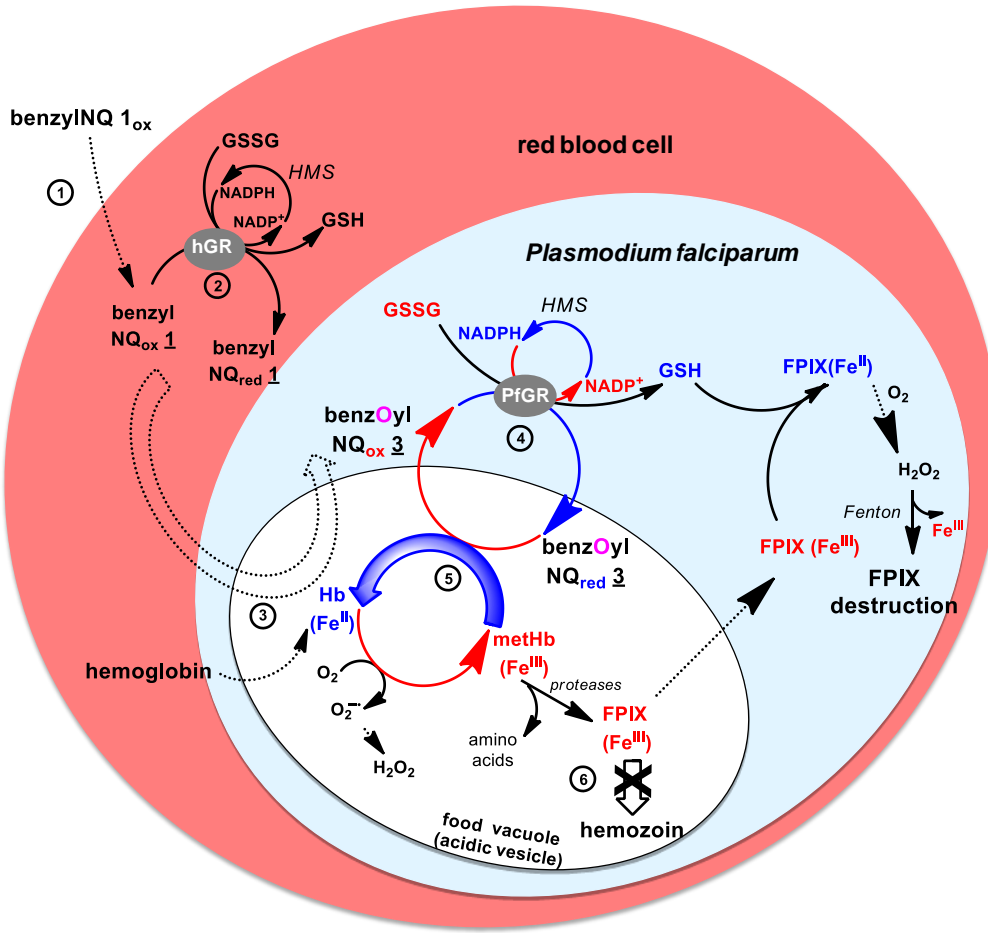

${ }^{a}$ HMS, hexose monophosphate shunt.
Blue arrows indicate reduction; red arrows oxidation. Dashed arrows represent uptake processes. The lead benzylNQ are proposed to be taken up by the infected red blood cells (step 1), to be reduced in the cytosol of the human red blood cell by human GR (step 2), and then to be oxidized at the benzylic chain to benzoylNQ in the acidic vesicles or in the food vacuole (step 3) in hemecatalyzed reactions. Subsequently, the benzoylNQ are proposed to be transported into the cytosols and reduced by GR of the human host cell (not shown) or of the parasite (step 4) in a continuous redox cycle. The reduced species of benzoylNQ are assumed to be transported through $\mathrm{Fe}^{\mathrm{III}}$ complexation into the acidic vesicles where the benzoylNQ $Q_{\text {red }}$ transfer the electrons to oxidants (hematin or metHb, step 5). The final result is an inhibition of hemozoin formation (step 6) and the arrest of trophozoite development as shown in Figure 8. Thus, the antimalarial benzylNQ would act as prodrugs of redox-active principles, being cycled in and out of the acidic vesicles in infected red blood cells, thereby oxidizing major intracellular reductants (NADPH) and subsequently reducing oxidants like hematin or metHb.

\section{Results}

2.1. Chemistry. We first synthesized a series of menadione, 5-hydroxymenadione (plumbagin) and 5azamenadione (6-methyl-quinoline-5,8-dione) analogues 1,2,5,7,9 functionalized at C-3 by a benzyl-chain carrying a broad array of various substituents and tested them for antimalarial activity (Scheme 3, see selected key structures in Figure 3). The silver-catalyzed radical decarboxylation reaction ${ }^{15}$ provides a powerful tool for a fast and easy access to 3-substituted-benzyl derivatives of menadione, plumbagin, and 6methylquinoline-5,8-dione in only one step in moderate to good yields (46-89\%, Scheme 3, Table S1 in the Supporting Information) tolerating a wide spectrum of functional groups except for the phenol and the carboxylic acid derivatives ( $7 \%$ for 1d, and $12 \%$ for 1f). After flash-chromatography all compounds were analytically pure and did not have to be further purified. The benzoylNQ derivatives $\mathbf{3}, \mathbf{4}$ were prepared as putative metabolites of the benzylNQ 1, 2. The benzoylNQ were obtained by oxidizing the corresponding benzylic compounds using chromium(VI) oxide and periodic acid as terminal oxidants (Scheme 3). ${ }^{16}$ The oxidation reactions from benzyl derivatives $\mathbf{1}, \mathbf{2}$ were performed at room temperature for 24 hours giving the desired benzoylNQ products 3a-f, 4a, 8a in moderate to good yields (33$67 \%$, Scheme 3, Table S1 in the Supporting Information).
Scheme 3. Synthesis of 3-Benzyl and 3-BenzoylSubstitued Derivatives of Menadione, Plumbagin, Difluo -romethylmenadione and 6-Methylquinoline-5,8-Dione. ${ }^{a}$

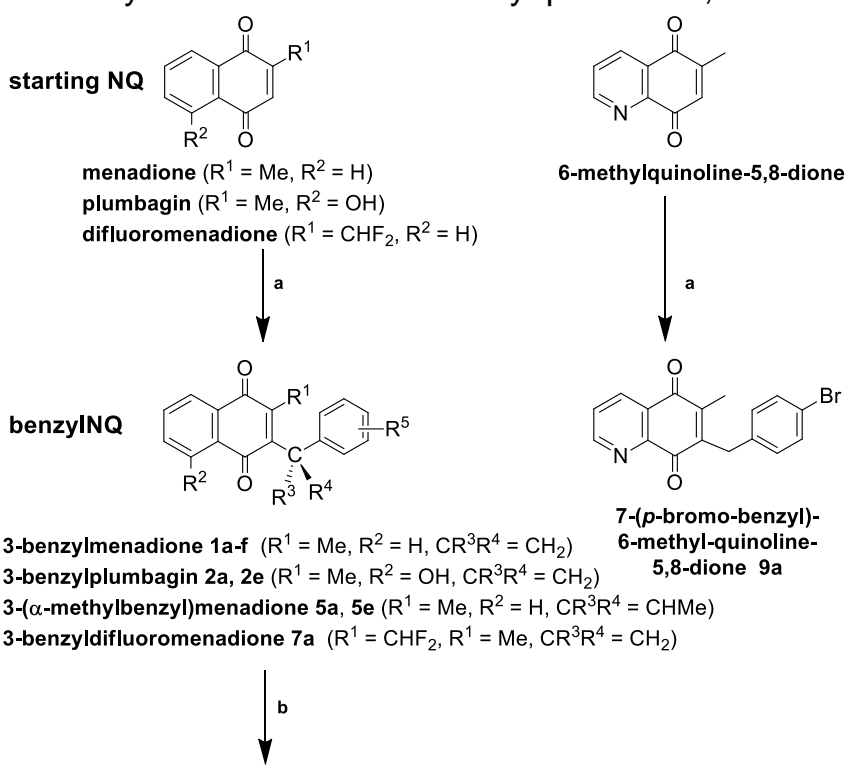

benzoyINQ

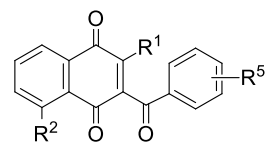

3-benzoylmenadione 3a-f $\left(R^{1}=M e, R^{2}=H\right)$

3-benzoylplumbagin 4a $\left(R^{1}=M e, R^{2}=O H\right)$

3-benzoyldifluoromenadione $8 a\left(R^{1}=C^{2} F_{2}, R^{1}=M e\right)$

${ }^{a}$ Reaction conditions: (a) phenylacetic acid derivative (2.0 equiv.), $\mathrm{AgNO}_{3}$ (0.1 equiv.), $\left(\mathrm{NH}_{4}\right)_{2} \mathrm{~S}_{2} \mathrm{O}_{8}$ (1.3 equiv.), 
$\mathrm{MeCN} /$ water 3/1, $85^{\circ} \mathrm{C}, 2 \mathrm{~h},\left(7-89 \%\right.$ ); (b) $\mathrm{CrO}_{3}$ (0.2 equiv.), $\mathrm{H}_{5} \mathrm{IO}_{6}$ (7.0 equiv.), MeCN, rt, 24 h, (33- $67 \%$ ).

The "benzhydrol" 6a was also prepared as a putative metabolite of 1a (Scheme 4). Its synthesis followed lithiation of the 2-methyl-3-bromo-1,4-dimethoxynaphthalene $\mathbf{1 1}$ and $p$-bromobenzaldehyde addition to give the benzhydrol intermediate 12. Oxidation with cerium ammonium nitrate (CAN) afforded the benzhydrol $\mathbf{6 a}$.

Scheme 4. Synthesis of the ( \pm )-3-(Phenylhydroxymethyl)menadione or "Benzhydrol" 6a. ${ }^{a}$
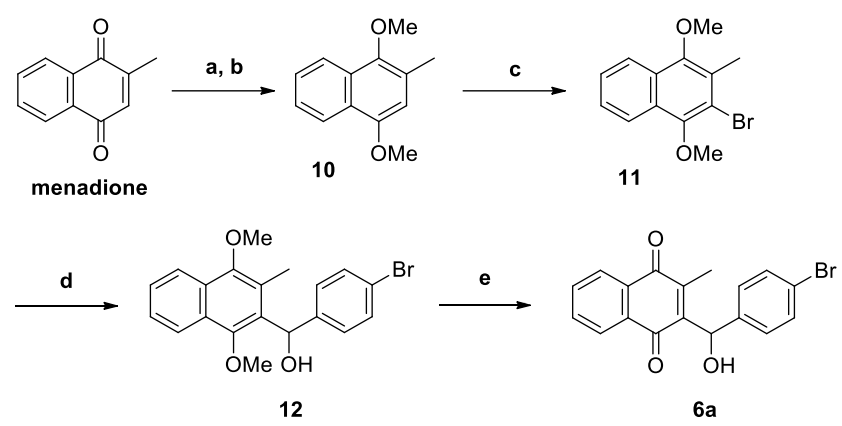

${ }^{a}$ Reaction conditions: (a) 2.5 equiv. $\mathrm{SnCl}_{2}, \mathrm{HCl}, \mathrm{EtOH}$, rt, $0.5 \mathrm{~h}$; (b) 5.0 equiv. $\mathrm{KOH}, 3.0$ equiv. $\mathrm{Me}_{2} \mathrm{SO}_{4}$, acetone, $60{ }^{\circ} \mathrm{C}$, $2 \mathrm{~h},(73 \%)$; (c) 1.0 equiv. $\mathrm{Br}_{2}, \mathrm{CH}_{2} \mathrm{Cl}_{2}, 0{ }^{\circ} \mathrm{C}, 1 \mathrm{~h}$, then rt, $2 \mathrm{~h}$, (73\%); (d) 1.05 equiv. ${ }^{\mathrm{n}} \mathrm{BuLi}, \mathrm{THF},-78{ }^{\circ} \mathrm{C}, 0.5 \mathrm{~h}$, then 1.0 equiv. $p$-bromobenzaldehyde, THF, $-78{ }^{\circ} \mathrm{C}, 10 \mathrm{~min}$, then $\mathrm{rt}$, $1 \mathrm{~h},(73 \%)$; (e) 3.0 equiv. $\mathrm{CAN}, \mathrm{CH}_{3} \mathrm{CN}, \mathrm{H}_{2} \mathrm{O}, \mathrm{rt}, 1 \mathrm{~h}(86 \%)$.

When the benzyl position of the phenylacetic acids was $\alpha$-alkylated the yields of the silver catalyzed decarboxylation were significantly lower $(\mathbf{5 a}, \mathbf{5 e}$, yields 25-29 \%, Table S1 in the Supporting Information). The compounds $\mathbf{5 a}$ and $\mathbf{5 e}$ were synthesized via the silvercatalyzed decarboxylation of $\alpha$-methyl phenylacetic acids, 15a and 15e, prepared from phenylacetic methyl esters (Scheme 5). In the case of $\mathbf{5 e}$ bearing a tert-butyl group in para-position the corresponding phenyl acetic acid was synthesized from methyl-p-tert-butylphenylacetate (Scheme 5) which was methylated in $\alpha$ position to obtain the $\alpha$-methylacid methyl ester $\mathbf{1 4 e}$.

Scheme 5. Synthesis of a-Alkylated Carboxylic Acids $15 \mathrm{a}$ and $15 \mathrm{e}$ and of 3-( $\alpha$-Methylbenzyl)menadione Derivatives $5 \mathbf{a}$ and $5 \mathbf{e}^{a}$
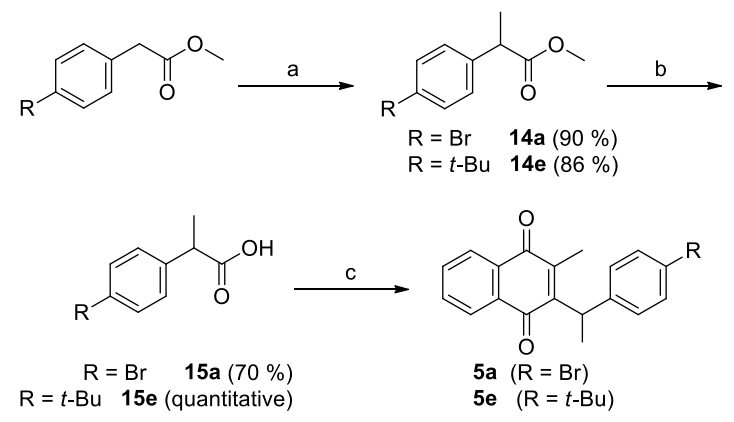

${ }^{a}$ Reaction conditions: (a) LDA, THF, $-78^{\circ} \mathrm{C}$, then MeI, (b) EtOH, KOH, $\mathrm{H}_{2} \mathrm{O}, \mathrm{RT}$; (c) menadione (1.0 equiv.), acid (2.0 equiv.), $\mathrm{CH}_{3} \mathrm{CN} / \mathrm{H}_{2} \mathrm{O}$ (v/ $/ \mathrm{v}=3 / 1$ ), 0.1 equiv. $\mathrm{AgNO}_{3}, 1.3$ equiv. $\left(\mathrm{NH}_{4}\right)_{2} \mathrm{~S}_{2} \mathrm{O}_{8}, 85^{\circ} \mathrm{C}, 3-4 \mathrm{~h}$.

The ester was finally hydrolyzed under basic conditions to obtain the corresponding carboxylic acid 15e in excellent yield. The same protocol was applied for the synthesis of the $\alpha$-methylphenylacetic acid 15a bearing a bromine atom in para-position, but from ethyl 4-bromophenylacetate as starting material.

The synthesis of the difluoromenadione derivative 7a was achieved in 5 steps via the straightforward synthesis of difluoromenadione, prepared by direct fluorination of 1,4-dimethoxy-naphthalene-2carbaldehyde 18 (Scheme 6). The introduction of the aldehyde function was almost quantitatively achieved (98 \%) by using 1,4-dimethoxy-naphthalene, dichloromethyl methyl ether and tin(IV) chloride as reagents. ${ }^{17}$ 2-Formyl-1,4-dimethoxy-naphthalene $\mathbf{1 8}$ was treated with DAST leading to the difluoromethylsubstituted 1,4-dimethoxynaphthalene $\mathbf{1 9}$ with an excellent yield $(90 \%)$. A standard oxidation using CAN as oxidant gave the difluoromenadione in $93 \%$ yield (Scheme 6). The benzylation of difluoromenadione was performed through the standard silver-catalyzed decarboxylation reaction of 4-bromo-phenylacetic acid as coupling partner to give 7a (Scheme 3). Finally, the general procedure for the oxidation of 3-benzyl derivatives using $\mathrm{CrO}_{3} / \mathrm{H}_{5} \mathrm{IO}_{6}$ was applied to $7 \mathbf{a}$ and led to its benzoyl derivative $8 \mathbf{a}$ in a good yield (78 \%).

Scheme 6. Preparation of 2-Difluoromenadione. ${ }^{a}$

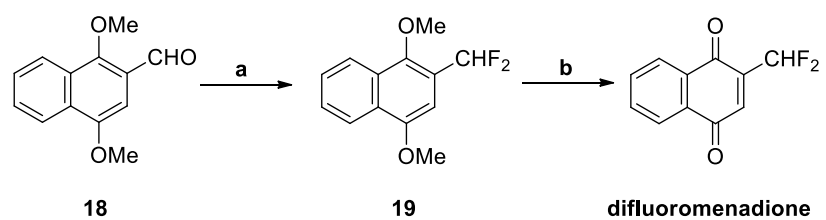

a Reaction conditions: (a) 2.0 equiv. DAST, under $\mathrm{N}_{2}$, rt, overnight (90\%); (b) 3.0 equiv. $\mathrm{CAN}, \mathrm{CH}_{3} \mathrm{CN}, \mathrm{H}_{2} \mathrm{O}, \mathrm{rt}, 1 \mathrm{~h}$, (93\%).

2.2. Antimalarial Activities. The library of representative NQ was tested for antimalarial effects using the ${ }^{3} \mathrm{H}$-hypoxanthine incorporation-based assay (Figure 4). ${ }^{18,19}$ Inhibition of the growth of $P$. falciparum by the compounds was evaluated by determining the inhibitor concentration required for killing $50 \%$ of the parasite ( $\mathrm{IC}_{50}$ values). In a screening assay all compounds were tested against the CQ-resistant $P$. falciparum strain Dd2. Six compounds were revealed with $\mathrm{IC}_{50}$ values below $100 \mathrm{nM}$ (Table in Figure 4). Key-structures are presented in Figure 3. The compounds belong to the 3-benzylmenadione series bearing halide- (1a, 1b, 1c), hydroxy- (1d) functions, nitrogen-based (1g) and alkyl-substituent (1e). As previously seen, the carboxylic acid function in $\mathbf{1 f}$ is not 
a favorable parameter for cell bioavalaibility. ${ }^{11 a, 12 a}$ In these assays, the standard drug CQ was also tested as reference displaying an $\mathrm{IC}_{50}$ value of $110 \mathrm{nM}$. Compared to the benzyl series, the corresponding benzoyl series displayed lower antimalarial activities with $\mathrm{IC}_{50}$ values being greater than $1 \mu \mathrm{M}$ except in the case of the nitro derivative $\mathbf{3 g}$.

Concerning the set of key compounds alkylated at the benzyl position they were designed to study the influence of the "blocked" benzyl position toward the antimalarial activity. The $3-(\alpha-$ methylbenzyl)menadione 5 series displayed a 3- to 6-fold decreased antimalarial activity. This suggests an oxidative bioactivation of the parent benzylNQ involving the benzyl chain as part of the mechanism of action. One explanation could be that the benzoyl metabolites need to be generated in the parasite to express their activity. Alternately, contrary to the parent benzylNQ, they might not be recognized by a putative transporter to be internalized by the parasite. This hypothesis remains to be confirmed in the future; we are preparing ${ }^{13} \mathrm{C}$-enriched benzylNQ representatives to study their metabolism in $P$. falciparum-infected erythrocytes by ${ }^{1} \mathrm{H}$ high resolution magic angle spinning NMR as previously applied for ethionamide pro-drug activation in mycobacteria. ${ }^{20}$
Figure 3. Structures of Key 3-Substituted Benzyl and Benzoyl Derivatives of Menadione, Plumbagin, Difluoromenadione and 6-Methylquinoline-5,8-Dione.
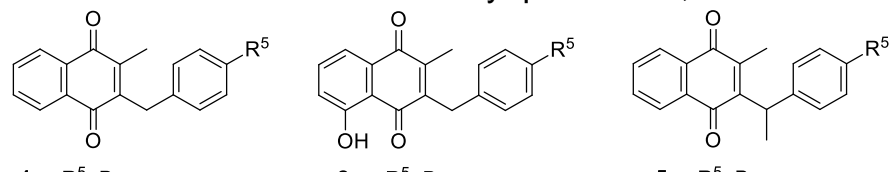

1a $\mathrm{R}^{5}=\mathrm{Br}$

1b $\mathrm{R}^{5}=\mathrm{F}$

1c $\mathrm{R}^{5}=\mathrm{CF}_{3}$

1d $\mathrm{R}^{5}=\mathrm{OH}$

1e $\mathrm{R}^{5}=t$-Bu

1f $\mathrm{R}^{5}=\mathrm{COOH}$

1 g $\mathrm{R}^{5}=\mathrm{NO}_{2}$

$$
\text { 2a } \mathrm{R}^{5}=\mathrm{Br}
$$

2e $\quad R^{5}=t-B u$

5a $\mathrm{R}^{5}=\mathrm{Br}$

5e $\mathrm{R}^{5}=t-\mathrm{Bu}$<smiles>O=C1C(Cc2ccc(Br)cc2)=C(C(F)F)C(=O)c2ccccc21</smiles><smiles>CC1=C(Cc2ccc(Br)cc2)C(=O)c2ncccc2C1=O</smiles>

$9 a$

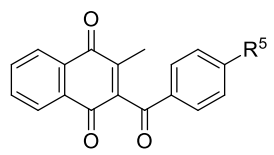<smiles>CC1=C(C(=O)c2ccc(Br)cc2)C(=O)c2c(O)cccc2C1=O</smiles>

$4 a$

$\begin{array}{ll}\text { 3a } & \mathrm{R}^{5}=\mathrm{Br} \\ \text { 3b } & \mathrm{R}^{5}=\mathrm{F}\end{array}$

3c $\mathrm{R}^{5}=\mathrm{CF}_{3}$

3d $\mathrm{R}^{5}=\mathrm{OH}$

3e $\mathrm{R}^{5}=t-\mathrm{Bu}$

3f $\mathrm{R}^{5}=\mathrm{COOH}$

3g $\mathrm{R}^{5}=\mathrm{NO}_{2}$<smiles>CC1=C(C(O)c2ccc(Br)cc2)C(=O)c2ccccc2C1=O</smiles><smiles>Cc1c(C(=O)c2ccc(C(F)(F)F)cc2F)c(O)c2ccccc2c1O</smiles>

Figure 4. In vitro Growth Inhibition of Malarial Parasites (Dd2) by Menadione Derivatives and Dose Response Curves for a Selected Number of 3-Benzyl- representatives. ${ }^{a}$

\begin{tabular}{c|c|c}
\hline \multirow{2}{*}{ Series } & compd & $\begin{array}{c}\text { IC } \\
\text { 50 }(\mathrm{nM}) \text { mean } \pm \\
\text { SEM }(\mathrm{n})\end{array}$ \\
\hline \multirow{4}{*}{ BenzylNQ } & $\mathbf{1 a}$ & $46 \pm 4(5)$ \\
\cline { 2 - 3 } & $\mathbf{1 b}$ & $79 \pm 6(3)$ \\
\cline { 2 - 3 } & $\mathbf{1 c}$ & $29 \pm 2(3)$ \\
\cline { 2 - 3 } & $\mathbf{1 d}$ & $55 \pm 5(3)$ \\
\cline { 2 - 3 } & $\mathbf{1 e}$ & $54 \pm 5(4)$ \\
\cline { 2 - 3 } & $\mathbf{1 f}$ & $900 \pm 100(2)$ \\
\cline { 2 - 3 } & $\mathbf{1 g}$ & $46 \pm 3(3)$ \\
\cline { 2 - 3 } & $\mathbf{2 a}$ & 190 \\
\hline F-benzyl & $\mathbf{2 a}$ & $>1,000$ \\
\hline azaNQ & $\mathbf{9 a}$ & 608 \\
\hline \multirow{2}{*}{ Me-benzylNQ } & $\mathbf{5 a}$ & 306 \\
\cline { 2 - 3 } & $\mathbf{5 e}$ & 218 \\
\hline \multirow{2}{*}{ BenzoylNQ } & $\mathbf{3 a - f}, \mathbf{4 a}$ & $>1,000$ \\
\cline { 2 - 3 } & $\mathbf{3 g}$ & 103 \\
\hline benzhydrol & $\mathbf{6 a}$ & 634 \\
\hline F-benzoyl & $\mathbf{8 a}$ & $>1,600$ \\
\hline Ref. & Chloroquine & $110 \pm 20(4)$ \\
\hline & \multicolumn{2}{|c}{}
\end{tabular}

A
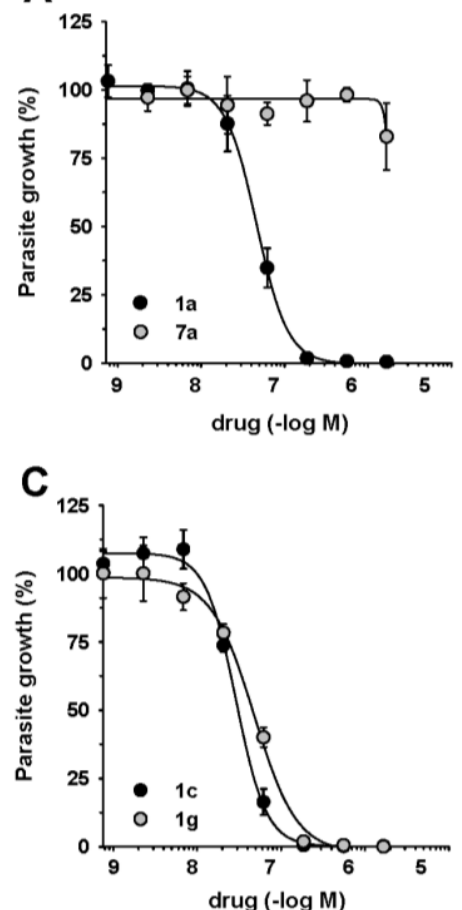

B

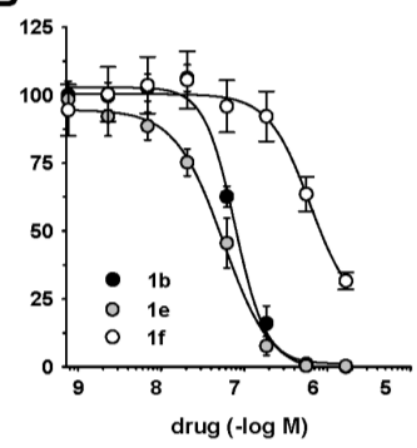

D

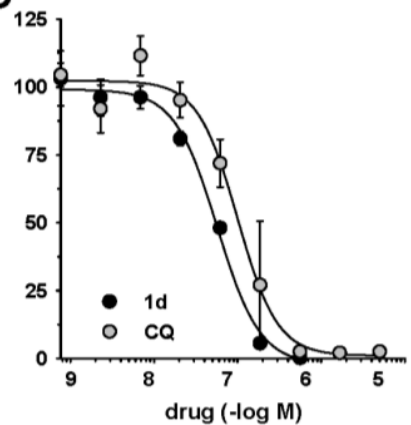




\begin{abstract}
${ }^{a}$ Table: the $\mathrm{IC}_{50}$ values were determined using the multi-drug resistant $P$. falciparum clone $\mathrm{Dd} 2$ in the ${ }^{3} \mathrm{H}$-hypoxanthine incorporation-based assay. ${ }^{18,19}$ Values are the mean \pm SEM of (n) independent determinations. The $\mathrm{IC}_{50}$ value of the antimalarial drug chloroquine is indicated as a reference. Panels A-D: Highly synchronized P. falciparum cultures were incubated with increasing concentrations of the compounds indicated and the percent of parasite growth was determined after $72 \mathrm{hrs}$ of drug exposure. The data points were fitted using a three parameter Hill function to calculate the $\mathrm{IC}_{50}$ values given in the Table. (A) compounds 1a (black symbol) and 7a (grey symbol). (B) compounds 1b (black symbol), 1e (grey symbol) and 1f (white symbol). (C) compounds 1c (black symbol) and 1g (grey symbol); (D) compounds 1d (black symbol) and chloroquine (CQ, grey symbol). The mean \pm SEM of at least three independent determinations is shown.
\end{abstract}

2.3. Glutathione Reductase Inhibition Studies. Determination of $I C_{50}$ values. As a consequence of their potential substrate competence, the 3-benzyl- and 3-benzoylmenadione analogues were first tested as inhibitors of both GRs in the standard $1 \mathrm{mM}$ GSSG reduction assay (Table in Figure 5). 2-Methyl-1,4naphthoquinone (menadione) was used as reference, displaying $\mathrm{IC}_{50}$ values of 42.0 and $27.5 \mu \mathrm{M}$ for $P$. falciparum GR and human GR respectively. All compounds (Figure 5) displayed higher GR inhibition potencies than the unsubstituted menadione. In addition, the 3-benzoylmenadiones $\mathbf{3}, \mathbf{4}$ behaved as the most potent GSSG reductase inhibitors described so far, with $\mathrm{IC}_{50}$ values up to 10 -fold lower than for the 3-benzyl analogues 1, 2 (Figure 5A). In general, all compounds showed a 1.25- to 9-fold stronger inhibition for human GR than for $P$. falciparum GR assuming a stronger interaction with human GR. Compound $3 f$ was then selected for detailed inhibition studies to determine the inhibition type and constants in $P$. falciparum GR assays.

Figure 5. Inhibition of the Glutathione Reductases from P. falciparum and Human by 3-Benzyl- and 3-Benzoyl Substituted Derivatives of Menadione and Dose Response Curves for the Selected 3-Benzyl-Menadione Derivatives $\mathbf{3 g}$ and $\mathbf{3 f}$ as Inhibitors of $P$. falciparum and Human Glutathione Reductases Under Steady-State Conditions. $^{a}$

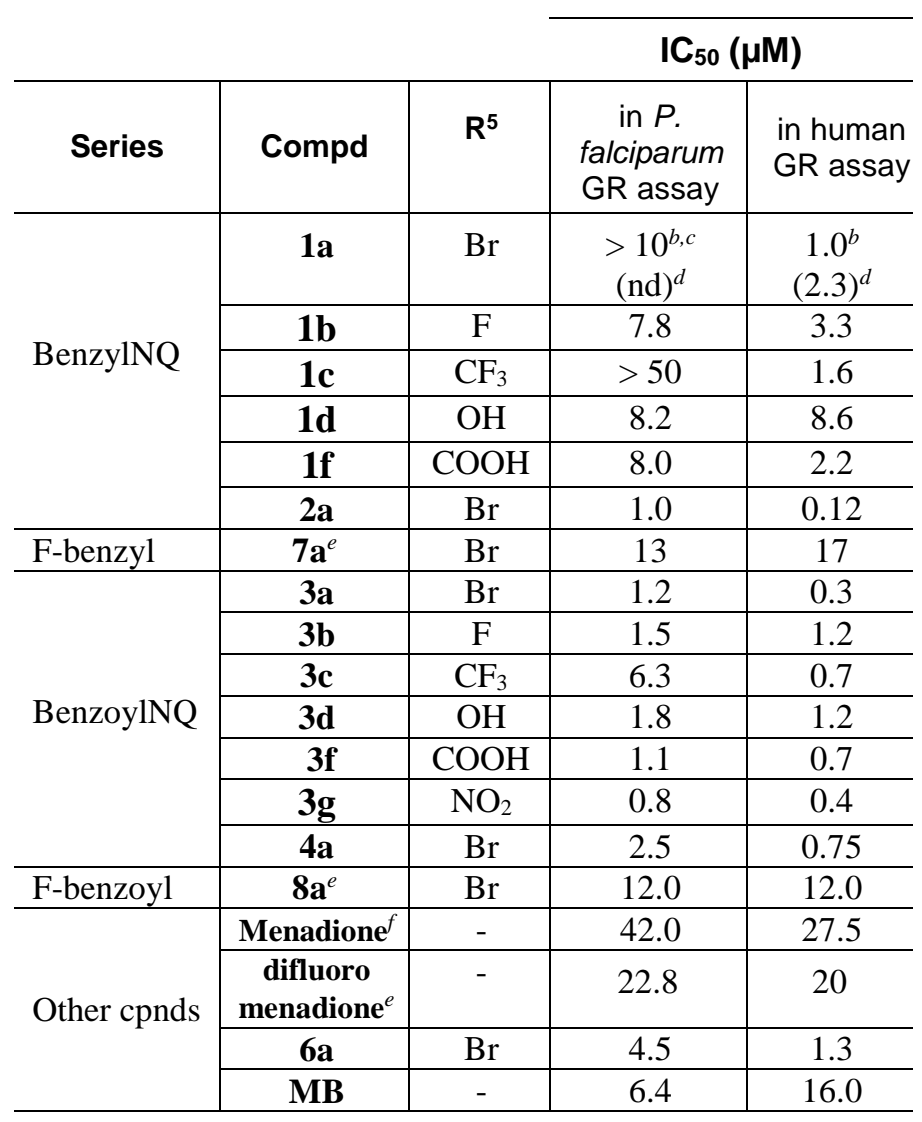
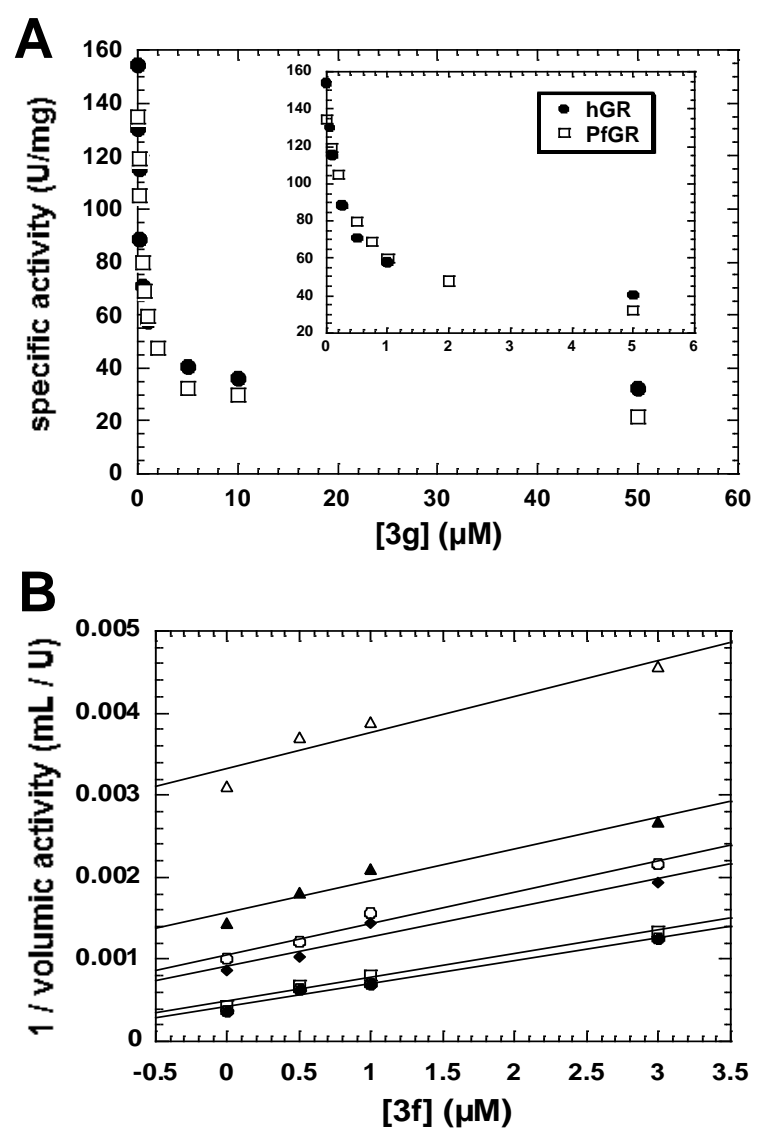

${ }^{a}$ Table: the values were determined at $\mathrm{pH} 6.9$ and $25{ }^{\circ} \mathrm{C}$ in the presence of $1 \mathrm{mM} \mathrm{GSSG} ;{ }^{b}$ in the presence of $5 \%$ DMSO; ${ }^{c}$ Reprecipitation of the compound in the cuvette prevented $\mathrm{IC}_{50}$ determination; ${ }^{d}$ in the presence of $1 \%$ DMSO; concomitant aggregation of the enzyme occurred; ${ }^{f}$ Data from ref. $11 \mathrm{~b}$; nd: not determined. Panel A: Dose response curves for the selected 3-benzylmenadione $\mathbf{3 g}$ as inhibitor of P. falciparum ( $\square$ ) and human (- glutathione reductases in the presence of $1 \mathrm{mM}$ GSSG as disulfide substrate and $100 \mu \mathrm{M}$ NADPH. Panel B: Dixon plot showing inhibition of $P$. falciparum GR-catalyzed GSSG reduction at a fixed NADPH concentration $(100 \mu \mathrm{M})$ in the presence of GSSG as variable substrate $(20(\Delta)-40(\boldsymbol{\Delta})-60(\circ)-100(\bullet)-400(\square)-1000(\bullet) \mu \mathrm{M})$ and increasing 3f concentration $(0-0.5-1-3$ 
Inhibition Type of $P$. falciparum and Human Glutathione Reductase Under Steady-State. In order to investigate the type of $P$. falciparum GR inhibition, kinetics were performed at various concentrations of both GSSG and potent inhibitor $\mathbf{3 f}$, in the presence of a saturating NADPH level. The data were fitted to the appropriate equation with Kaleidagraph using a computerized least-square regression program. With GSSG $(20-1000 \mu \mathrm{M})$ as variable substrate and NADPH at a constant concentration of $100 \mu \mathrm{M}$, the $K_{\mathrm{m}}$ value of GSSG in the absence of inhibitor was found to be 144.4 $\pm 15.7 \mu \mathrm{M}$. The inhibition of P. falciparum GR by $\mathbf{3 f}$ $(0-3 \mu \mathrm{M})$ was found uncompetitive with respect to GSSG. The $K_{\mathrm{i}}$ value for $\mathbf{3 f}$ was determined as $1.0 \pm$ $0.06 \mu \mathrm{M}$ from the secondary plot expressing $1+[\mathrm{I}] / K_{\mathrm{i}}$ as a linear function of inhibitor concentration. The uncompetitive type of inhibition of $P$. falciparum GR by $3 \mathbf{f}$ was deduced from Cornish-Bowden, LineweaverBurk, and Dixon (Figure 5B) plots. In the human GR assay also assuming uncompetitive inhibition, the $K_{\mathrm{i}}$ value for $\mathbf{3 f}$ was determined as $0.64 \pm 0.02 \mu \mathrm{M}$ with respect to GSSG.

Glutathione Reductase-Catalyzed Naphthoquinone Reductase Activity. The ability of $P$. falciparum GR to reduce the 1,4-naphthoquinones was studied in vitro by following the oxidation of NADPH in the presence of various 3-benzyl- and 3-benzoyl menadione derivatives and compared with menadione itself as reference (Table 1 ). The NQ reductase activity of $P$. falciparum GR was compared to the intrinsic NADPH oxidation activity of the enzyme in the absence of the NQ. The catalytic parameters of menadione against $P$. falciparum GR were shown ${ }^{11 \mathrm{a}}$ to be $82.2 \mu \mathrm{M}$ and $9.6 \mathrm{~min}^{-1}$ for $K_{\mathrm{m}}$ and $k_{\text {cat }}$, respectively, leading to a catalytic efficiency $k_{\text {cat }} / K_{\mathrm{m}}$ of $1.99 \mathrm{mM}^{-1} \mathrm{~s}^{-1}$ (Table 1).

Table 1. Plasmodium falciparum Glutathione Reductase-Catalyzed Naphthoquinone Reduction. ${ }^{a}$

\begin{tabular}{|c|c|c|c|c|c|}
\hline \multirow[b]{2}{*}{ Series } & \multirow[b]{2}{*}{ compd } & \multirow[b]{2}{*}{$\mathrm{R}^{5}$} & \multicolumn{3}{|c|}{$\begin{array}{l}\text { Naphthoquinone } \\
\text { reductase } \\
\text { activity of } P f G R^{[a]}\end{array}$} \\
\hline & & & $\begin{array}{c}K_{\mathrm{m}} \\
(\mu \mathrm{M})\end{array}$ & $\begin{array}{c}k_{\text {cat }} \\
\left(\mathrm{min}^{-1}\right)\end{array}$ & $\begin{array}{l}k_{\text {cat }} / K_{\mathrm{m}} \\
\left(\mathrm{mM}^{-1} \mathrm{~s}^{-1}\right)\end{array}$ \\
\hline \multirow{3}{*}{ Benzyl } & $1 \mathrm{a}$ & $\mathrm{Br}$ & $\mathrm{nd}^{b}$ & $\mathrm{nd}^{b}$ & $\mathrm{nd}^{b}$ \\
\hline & $1 b$ & $\mathrm{~F}$ & 26 & 2.53 & 1.62 \\
\hline & 1d & $\mathrm{OH}$ & 67 & 2.54 & 0.64 \\
\hline \multirow{6}{*}{ Benzoyl } & 3a & $\mathrm{Br}$ & 6.1 & 2.31 & 6.31 \\
\hline & $3 b$ & $\mathrm{~F}$ & 56.1 & 16.7 & 4.96 \\
\hline & $3 c$ & $\mathrm{CF}_{3}$ & 42.4 & 3.36 & 1.32 \\
\hline & 3d & $\mathrm{OH}$ & 84.2 & 26.6 & 5.26 \\
\hline & $3 g$ & $\mathrm{NO}_{2}$ & 18 & 8.38 & 7.76 \\
\hline & $3 f$ & $\mathrm{COOH}$ & 1325 & 111.6 & 1.4 \\
\hline
\end{tabular}


dithiol. ${ }^{1 \mathrm{~b}}$ Noteworthy is the previous observation made with these monofluorine-based suicide-substrates of glutathione reductases: irreversible GR inhibition did not lead to increased antimalarial effects but instead to increased toxicity towards human cells.

Scheme 7. Time-Dependent Inactivation of Human Glutathione Reductase by Monofluoromenadione Derivatives.
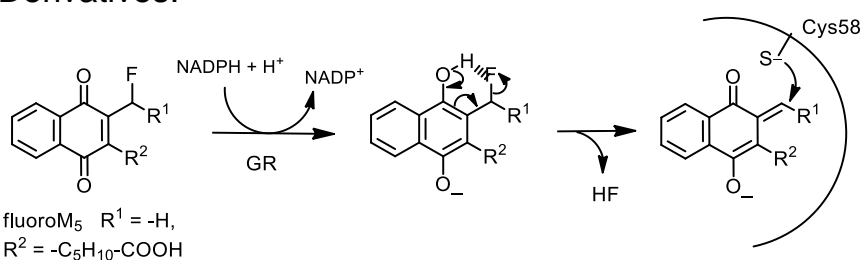

fluorom $\mathrm{R}_{5} \mathrm{R}^{1}=-\mathrm{H}$,

$\mathrm{R}^{2}=-\mathrm{C}_{5} \mathrm{H}_{10}-\mathrm{COOH}$

The presence of one, two or three fluorine atoms has an influence on the oxidant character of the parent menadione core. The electrochemical properties of the fluoromethyl compounds were investigated by cyclic voltammetry under the conditions previously described. ${ }^{1 \mathrm{~b}}$ Both with the trifluoromenadione $\left(\mathrm{E}^{\circ}{ }_{1}=\right.$ $0.308 \mathrm{~V} /$ standard calomel electrode (SCE)), and the difluoromenadione $\left(\mathrm{E}^{\circ}{ }_{1}=-0.385 \mathrm{~V} / \mathrm{SCE}\right)$ one-electron reduction occurred at less negative values than with menadione used as reference $\left(\mathrm{E}^{\circ}{ }_{1}=-0.650 \mathrm{~V} / \mathrm{SCE}\right)$. These values make these two fluoro analogues of menadione strong oxidants and potential effective substrates of both glutathione reductases. By contrast to menadione showing redox reactions kinetically reversible in the cyclic voltammogram (data not shown) the formation of the quinone methide species followed by polymerization in the case of the difluoromenadione might be responsible for the non reversibility of the electron transfer reactions. These observations are in agreement with earlier literature, ${ }^{11 \mathrm{~b}, 21}$ rendering the difluoromenadione more prone to act as a suicidesubstrate.

When following NADPH consumption at $340 \mathrm{~nm}$ in the enzymic assays, the difluoromenadione was reduced by $P$. falciparum GR with a catalytic efficiency $k_{\text {cat }} / K_{\mathrm{m}}$ of $155.9 \mathrm{mM}^{-1} \mathrm{~s}^{-1}$, a value 12.7 -fold lower than that determined for the physiological substrate GSSG but 82 -fold higher than that determined for menadione (Table 2).

Table 2. Kinetic Parameters of Human and $P$. falciparum Glutathione Reductases with Fluoromethyl Analogues of Menadione as Substrates.

\begin{tabular}{ccccc}
\hline compd & $\begin{array}{c}\mathrm{GR} \\
\text { species }\end{array}$ & $\begin{array}{c}K_{\mathrm{m}} \\
(\mu \mathrm{M})\end{array}$ & $\begin{array}{c}k_{\mathrm{cat}} \\
\left(\mathrm{s}^{-1}\right)\end{array}$ & $\begin{array}{c}k_{\text {cat }} / K_{\mathrm{m}} \\
\left(\mathrm{mM}^{-1} \mathrm{~s}^{-1}\right)\end{array}$ \\
\hline $\begin{array}{c}\text { menadione } \\
\text { menadione }\end{array}$ & $h$ & 31.2 & 0.16 & 5.1 \\
$\begin{array}{c}\text { difluoro } \\
\text { menadione }\end{array}$ & $h$ & 67.4 & 0.17 & 1.9 \\
& & & 6.7 & 101.4
\end{tabular}

$\begin{array}{ccccc}\begin{array}{c}\text { difluoro } \\ \text { menadione }\end{array} & P f & 82.1 & 12.8 & 155.9\end{array}$

With the difluoromenadione, 7a (benzylNQ) and 8a (benzoylNQ) - the two difluoromethyl analogues of the 3-benzyl- and the 3-benzoyl-menadione derivatives 1a and 3a, respectively, time-dependent inhibition of the GRs from man and P. falciparum was studied using the $1 \mathrm{mM}$ GSSG reduction assay to evaluate the residual activity of reacted enzymes. Upon incubation with NADPH and the suicide-substrates, inactivation of human GR by the three compounds followed pseudofirst order reaction kinetics. The experimental data allowed the application of the derivation by Kitz and Wilson $^{22}$ for irreversible inactivation. A semilogarithmic plot of the fraction of non-inhibited enzyme activity $\ln \left(v_{\mathrm{i}} / v_{0}\right)$ versus incubation time yielded straight lines with increasing slopes at short time periods, equivalent to the apparent rate constant of irreversible inhibition $\left(k_{\text {obs }}\right)$. The secondary plot expressing $k_{\text {obs }}$ as a function of inhibitor concentration followed the equation 3:

$$
k_{\mathrm{obs}}=\frac{k_{\mathrm{i}}[\mathrm{I}]}{K_{\mathrm{I}}+[\mathrm{I}]}
$$

where $K_{\mathrm{I}}$ is the dissociation constant of the inhibitorenzyme complex and $k_{\mathrm{i}}$ is the first order rate constant for irreversible inactivation, respectively. The $k_{\mathrm{obs}}$ data versus [8a] (or [7a] or [difluoromenadione]) were fitted to equation 3 which resulted in the hyperbolic curve and the determination of the dissociation constant for the 8a-GR, the 7a-GR and difluoromenadione-GR complexes and the first order rate constant for irreversible inactivation, respectively, as $K_{\mathrm{I}}=8.9 \pm 4.0$ $\mu \mathrm{M}$ and $k_{i}$ as $9.0 \pm 1.8 \mathrm{~min}^{-1}$ for $\mathbf{8 a}$ (versus $16.8 \mu \mathrm{M}$ and $0.025 \mathrm{~min}^{-1}$ for $7 \mathbf{a}$ and $66.2 \mu \mathrm{M}$ and $7.0 \mathrm{~min}^{-1}$ for the difluoromenadione), allowing estimation of a second order rate constant $k_{i} / K_{\mathrm{I}}$ as $16.9 \mathrm{~mm}^{-1} \mathrm{~s}^{-1}$ for $8 \mathbf{a}$ versus 0.025 for $7 \mathbf{a}$ and $1.8 \mathrm{mM}^{-1} \mathrm{~s}^{-1}$ for difluoromenadione (Table 3$)$. The resulting half-times $\left(t_{1 / 2}\right)$ of inactivation of the human GR were determined as $0.1 \mathrm{~min}$ and below $0.1 \mathrm{~min}$ for the difluoromenadione and $\mathbf{8 a}$, respectively versus $27.7 \mathrm{~min}$ for $\mathbf{7 a}$ (Table 3 ).

Table 3. Selected Kinetic Parameters of Human Glutathione Reductase Inactivation by Fluoro Menadione Analogues.

\begin{tabular}{lcccc}
\hline compd & $\begin{array}{c}t_{1 / 2} \\
(\mathrm{~min})\end{array}$ & $\begin{array}{c}K_{\mathrm{l}} \\
(\mu \mathrm{M})\end{array}$ & $\begin{array}{c}k_{\mathrm{i}} \\
\left(\mathrm{min}^{-1}\right)\end{array}$ & $\begin{array}{c}k_{\mathrm{i}} / K_{\mathrm{I}} \\
\left(\mathrm{mM}^{-1} \mathrm{~s}^{-1}\right)\end{array}$ \\
\hline $\begin{array}{l}\text { difluoro } \\
\text { menadione }\end{array}$ & 0.1 & 66.2 & 7.0 & 1.8 \\
7a & 27.7 & 16.8 & 0.025 & 0.025 \\
$\mathbf{8 a}$ & 0.08 & 8.9 & 9.0 & 16.9 \\
\hline
\end{tabular}

Interestingly, the $\mathrm{IC}_{50}$ values of the difluoronaphthoquinones (difluoromenadione, 7a, 8a) determined in GR-catalyzed GSSG reduction assays 
under steady conditions were found to be one order of magnitude higher than the values for the benzoylNQ series, 3a-g (see Table in Figure 5). The dose response curves for the 3-benzoyl-menadione $\mathbf{3 a}$ and -difluoromenadione 8a derivatives in GSSG reduction assays in the presence of the human GR are shown in Figure 6. They are thought to result from two events: NADPH consumption due to GSSG reduction catalyzed by free homodimeric human GR in solution and polymerization of the difluoro quinone methide generated from the difluoromenadione derivative in the presence of the reduced enzyme. The high reactivity of the difluoro quinone methide intermediate is likely to act as a crosslinking reagent, by analogy to acrolein and its difluoro analogue in polyacroleins formation (see chart below). ${ }^{23}$
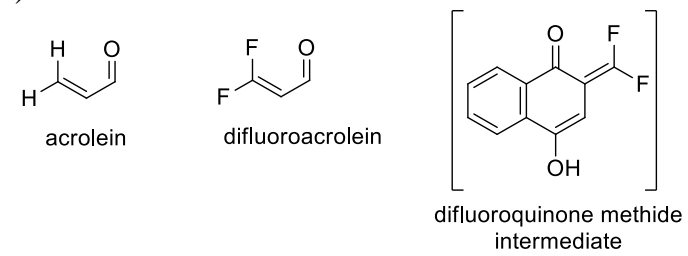

Figure 6. Dose Response Curves for the 3-BenzoylMenadione 3a and -Difluoromenadione 8a Derivatives As Human Glutathione Reductase Inhibitors under Steady-State Conditions. ${ }^{a}$

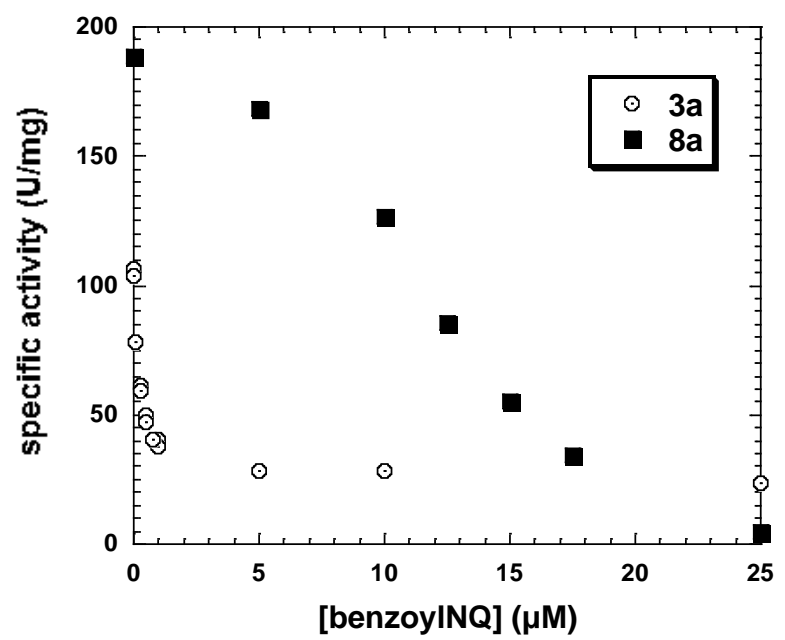

a From the dose response curves recorded at $\mathrm{pH} 6.9$ and $25^{\circ} \mathrm{C}$ in the presence of $1 \mathrm{mM}$ GSSG as disulfide substrate, $100 \mu \mathrm{M}$ NADPH, and $1 \%$ DMSO the $\mathrm{IC}_{50}$ values for the selected 3-benzoylmenadione derivatives 3a $(\odot)$ and $\mathbf{8 a}(\mathbf{\square})$ were determined as 0.3 and $12 \mu \mathrm{M}$, respectively.

The results are consistent with our concept of an irreversible mechanism-based inhibition by 3-benzoyldifluoromenadione derivatives. In additional kinetic experiments (data not shown), we observed that Plasmodium GR was also quickly inactivated upon incubation of the enzymes with NADPH and 8a. The first order rate constant $k_{i}$ for irreversible inactivation could not be determined because of the concomitant inactivation of the parasitic enzyme by NADPH itself in open air. ${ }^{1 \mathrm{lb}}$ Thus, the irreversible GR inactivation by a fluorine-based suicide-substrate of both GRs designed to be generated from 7a in the parasites, the benzoylNQ 8a, was accompanied by a complete loss of the antimalarial activity of both the 3-benzylmenadione $\mathbf{7 a}$, and the 3-benzoylmenadione 8a. These results suggest the essential requirement of an active GR (either the human or the parasitic enzyme, or both) in the drug bioactivation of the antimalarial lead benzylNQ $1 \mathbf{1 a}$.

\subsection{Methemoglobin Reduction in the Presence} of the Redox-Active benzoylNQ. To evaluate the reduction of metHb to $\mathrm{Hb}$ we set up an assay using the benzoylNQ, metHb( $\left.\mathrm{Fe}^{\mathrm{III}}\right)$ and the glutathione reductase/NADPH-based system to regenerate the hydronaphthoquinone continuously. The UV-spectrum of metHb between $300 \mathrm{~nm}$ and $700 \mathrm{~nm}$ is characterized by a maximal absorbance at $405 \mathrm{~nm}$, and a broad band centered at $630 \mathrm{~nm}$. The figure 7A displays reduction of metHb in the presence of the benzoylNQ 3d, characterized by a $k_{\text {cat }} / K_{\mathrm{m}}$ of $5.26 \mathrm{mM}^{-1} \mathrm{~s}^{-1}$, continuously reduced by the human GR/NADPH-based system. Upon metHb reduction the spectrum of $\mathrm{Hb}\left(\mathrm{Fe}^{\mathrm{II}}\right)$ showed a shift of the maximal absorbance from $405 \mathrm{~nm}$ to $410 \mathrm{~nm}$ and two weak bands at 536 and $576 \mathrm{~nm}$ (Figure 7A). MB with a $k_{\text {cat }} / K_{\mathrm{m}}$ value of $13.7 \mathrm{mM}^{-1} \mathrm{~s}^{-1}$ was used as a positive control of this effect (Figure 7B). In the coupled assay the shift of the maximal absorbance from $405 \mathrm{~nm}$ to $410 \mathrm{~nm}$ is already visible at $20 \mu \mathrm{M} \mathrm{MB}$, or at $100 \mu \mathrm{M}$ menadione (data not shown), or at $50 \mu \mathrm{M}$ benzoylNQ 3d. As expected, no band shift was observed in the presence of CQ instead of the benzoylNQ nor in the presence of MB (Figure 7C).

In order to confirm the electron transfer from the reduced 3-benzylnaphthoquinones to $\mathrm{MetHb}\left(\mathrm{Fe}^{\mathrm{III}}\right)$ the direct reduction of methemoglobin $\mathrm{MetHb}\left(\mathrm{Fe}^{\mathrm{III}}\right)$ by a 3benzoyl-dihydronaphthoquinone derivative was evaluated (in the absence of the GR/NADPH system). Because the 3-benzoyl-dihydronaphthoquinone derivatives are quite unstable in open air and very prone to be quickly re-oxidized into naphthoquinones, a "stabilized" 3-benzoyl-dihydronaphthoquinone derivative 20 (Figure 3), was prepared. This compound possesses a fluorine atom in ortho position to the methanone group which likely stabilizes the $\beta$ hydroxyketone bridge via hydrogen bonds. In that case a complete reduction of met $\mathrm{Hb}\left(\mathrm{Fe}^{\mathrm{III}}\right)$ to $\mathrm{Hb}\left(\mathrm{Fe}^{\mathrm{II}}\right)$ was observed in 2 minutes in the absence of the regenerating GR/NADPH system (Figure 7D).

\subsection{Cytotoxic Activities Against Human Cells} in Vitro. Noteworthy is the absence of hemolysis of infected and non-infected red blood cells, at the highest $\mu \mathrm{M}$ drug concentrations tested $(30 \mu \mathrm{M})$. In addition, all compounds were tested for cytotoxicity against two human cell lines, the human buccal carcinoma cell line cell (KB) and the human lung MRC-5 fibroblasts, by using the Alamar blue assay (Table S2 in the 
Supporting Information). Most of the 1,4naphthoquinone derivatives exhibited a low cytotoxicity profile against both human $\mathrm{KB}$ and MRC-5 cell lines as evidenced by the high $\mathrm{IC}_{50}$ values above $32 \mu \mathrm{M}$. The toxicity of the two derivatives, 3-benzyldifluoromenadione $7 \mathbf{a}$ and the oxidant azamenadione $\mathbf{9 a}$, probably stems from the higher lipophilicity due to the presence of fluorine atoms and/or from their high oxidant character, ${ }^{11 \mathrm{c}}$ respectively. Furthermore, when tested in Ames test the lead benzylNQ 1c, up to $100 \mu \mathrm{M}$, did not induce mutagenicity using three strains of Salmonella thyphimurium TA98, TA100 and TA1535 (the complete data of the genotoxicity study will be published elsewhere).

Figure 7. Methemoglobin Reduction by the Glutathione Reductase/NADPH-Reduced Redox-Active Agents, BenzoyINQ 3d or Methylene Blue, or Through the Direct Reaction with the 3-Benzoyl-Dihydronaphthoquinone 20. ${ }^{a}$
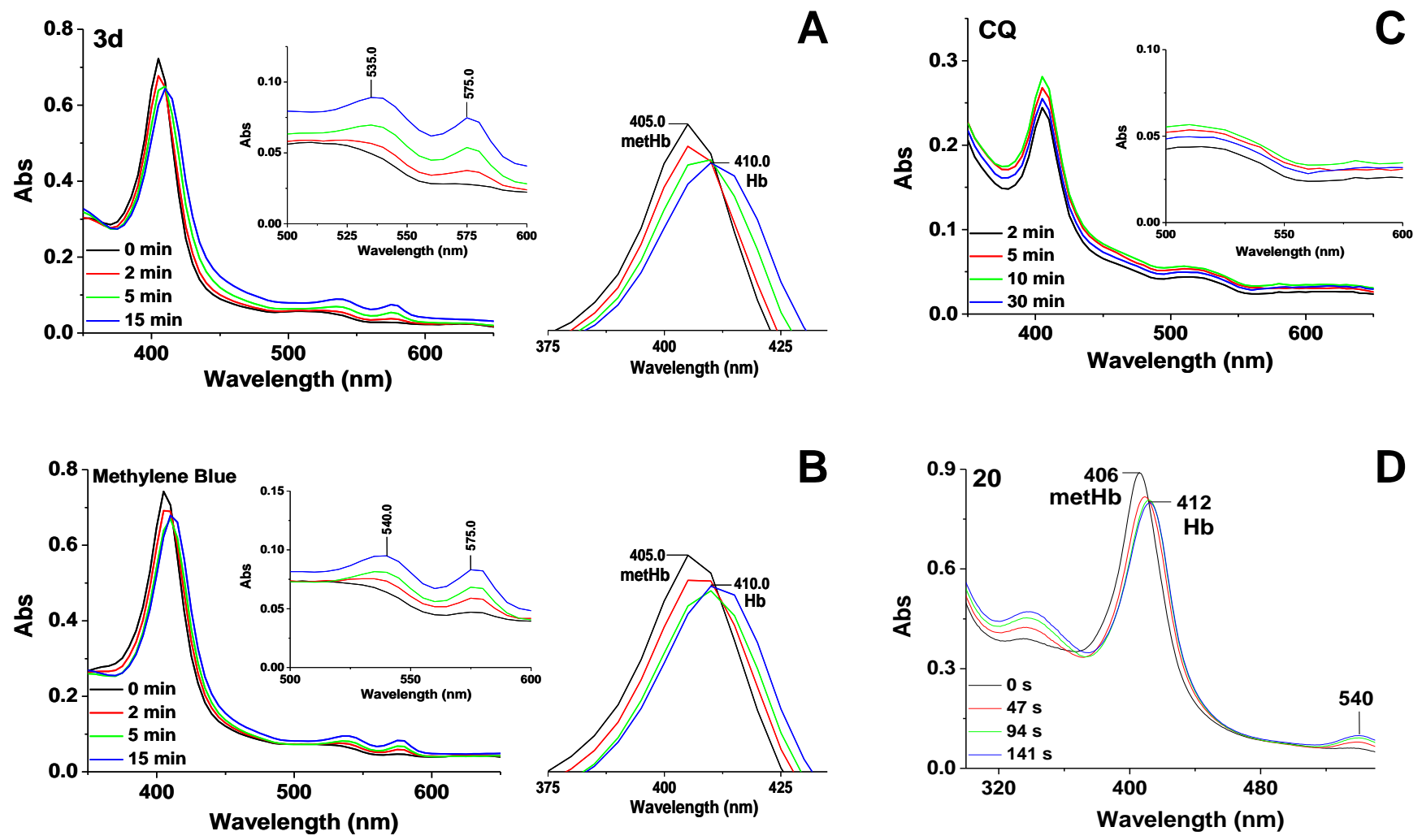

${ }^{a} \mathrm{UV}-\mathrm{Vis}$ absorption spectra evidencing the reduction of metHb(Fe $\left.\mathrm{Fe}^{\mathrm{III}}\right)$ to $\mathrm{Hb}\left(\mathrm{Fe}^{\mathrm{II}}\right)$ in the coupled assay based on the human GR/NADPH system in the presence of the subversive substrate benzoylNQ 3d, or $\mathbf{M B}$, and the direct reduction of metHb(Fe $\left.{ }^{\mathrm{III}}\right)$ to $\mathrm{Hb}\left(\mathrm{Fe}^{\mathrm{II}}\right)$ by the dihydrobenzoylNQ 20. Panel A: The reaction of $200 \mu \mathrm{M} 3 \mathbf{d}$ in the presence of $100 \mu \mathrm{M} \mathrm{metHb}, 400 \mu \mathrm{M}$ $\mathrm{NADPH}, 1 \mu \mathrm{mol}$ human GR, final [DMSO] $1 \%$, at $37^{\circ} \mathrm{C}$ caused a shift in the $\lambda_{\max }$ of metHb (from 405 to $410 \mathrm{~nm}$ ). Spectra were measured at different times over a $15 \mathrm{~min}$ period following addition of $20 \mu \mathrm{L}$ of the reaction mixture to a $1 \mathrm{~mL}-\mathrm{cuvette}$ containing GR buffer, pH 6.9. Panel B: Methylene blue was used as a positive control under the same conditions; a clear shift of $\lambda_{\max }$ of metHb was observed from 405 to $410 \mathrm{~nm}$. Panel C: CQ was used as a negative control. As expected, no shift was observed in the presence of CQ. The conditions used in the reaction mixture were $50 \mu \mathrm{M}$ metHb, $100 \mu \mathrm{M} \mathrm{CQ}, 200 \mu \mathrm{M}$ $\mathrm{NADPH}$, and $1.06 \mu \mathrm{mol} \mathrm{hGR}$, final [DMSO] $1 \%, 37^{\circ} \mathrm{C}$. Panel D: The conditions used in the reaction mixture were $2 \mu \mathrm{M}$ metHb, $40 \mu \mathrm{M}$ dihydrobenzoylNQ 20, final [DMSO] $2 \%$ in GR buffer, $\mathrm{pH} 6.9$, at $37.5^{\circ} \mathrm{C}$. The reaction was started directly in the cuvette and UV-Vis absorption spectra were recorded as a function of time.

2.7. Antimalarial Activities in Plasmodium berghei-Infected Mice. Five of the most active compounds (1a, 1c, 1d, 1e, 1g) which had successfully passed all studies with parasites in cultures were subsequently tested for their antimalarial action in vivo using the murine CD1 malaria model infected by the CQ-susceptible ANKA strain of P. berghei. Results of in vivo screens for the five compounds conducted according to the Peters's four-day test are given in Table 4. For comparative purposes, data for CQ and the five derivatives upon intraperitoneal administration (ip) acquired in the same screens were included. The untreated control group showed no decrease in parasitemia after ip or oral (po) administration. CQ as reference was applied at a dose of $10 \mathrm{mg} / \mathrm{kg}$ ip and po; the parasitemia decreased by $94.9 \%$ and by $98.8 \%$, respectively. Compounds 1a, 1c, 1d, 1 e and $\mathbf{1 g}$ showed significant activity following a 4-day treatment.

Table 4. Reduction of Parasitemia in CD1 Mice Infected with Plasmodium berghei Strain ANKA. ${ }^{a}$ 


\begin{tabular}{ccccc} 
compd & $\begin{array}{c}\text { Dose } \\
(\mathrm{mg} / \mathrm{kg} \times 4)\end{array}$ & $\begin{array}{c}\text { reduction } \\
\mathbf{i p}^{b}(\%)\end{array}$ & $\begin{array}{c}\text { reduction } \\
\mathbf{p o}^{b}(\%)\end{array}$ & $\mathbf{p}^{\text {-value }}$ \\
\hline $\begin{array}{c}\text { Untreated } \\
\text { control }\end{array}$ & - & 0 & 0 & - \\
\hline $\mathbf{C Q}^{a}$ & 10 & 94.9 & 98.8 & 0.0079 \\
\hline 1a & 30 & - & 0 & $\mathrm{~ns}$ \\
\hline 1a & 50 & 35.6 & 0.8 & 0.0079 \\
\hline $\mathbf{1 c}$ & 30 & 20.7 & - & $\mathrm{ns}$ \\
\hline $\mathbf{1 d}$ & 30 & 28.4 & - & $\mathrm{ns}$ \\
\hline $\mathbf{1 g}$ & 30 & 42.4 & 10.4 & $\mathrm{~ns}$ \\
\hline $\mathbf{1 e}$ & 30 & 43.4 & 34.9 & 0.0079 \\
\hline
\end{tabular}

${ }^{a}$ in this assay, at $1.0 \mathrm{mg} / \mathrm{kg}, 3.0 \mathrm{mg} / \mathrm{kg}$ and $10.0 \mathrm{mg} / \mathrm{kg}$ po chloroquine displayed a reduction of the parasitemia of 2.5 , 16.6 and $94.9 \%$, respectively. $b$ ip and po stand for intraperitoneal and oral administration, respectively. c calculated in the two-tailed Mann-Whitney $U$ test on the differences of treated versus untreated mice. ns means non significant.

Compound 1a was administered at $50 \mathrm{mg} / \mathrm{kg}$ and 30 $\mathrm{mg} / \mathrm{kg}$ per day. There was no significant inhibition when the compound was given orally but there was a significant effect $-35.6 \%$ inhibition (p-value $=0.0079)$ - when given intraperitoneally at $50 \mathrm{mg} / \mathrm{kg}$. The two most active drugs $\mathbf{1 e}(t$-Bu derivative) and $\mathbf{1 g}$ (nitro derivative) caused $43.4 \%$ and $42.4 \%$ reduction of parasitemia, using a daily dose of $30 \mathrm{mg} / \mathrm{kg}$ ip, respectively. At this dose level, $\mathbf{1 c}\left(\mathrm{CF}_{3}\right.$ derivative $)$ and 1d (phenol) displayed 20.7 to $28.4 \%$ decrease of parasitemia, suggesting a poor bioavailability or a high rate of drug clearance due to rapid elimination in the host. Upon oral administration of the two most active drugs $1 \mathrm{e}$ and $1 \mathrm{~g}$ at $30 \mathrm{mg} / \mathrm{kg}$ per day the parasitemia was reduced to 34.9 and $10.4 \%$, respectively. So far the efficiency of 1a has been improved by preparing a metabolically-resistant analogue by introduction of a $t$ $\mathrm{Bu}$ group in the critical position for biooxidation. ${ }^{24}$ The data in Table 4 support an oxidative metabolism in vivo (see 1a data versus 1e data), i.e. 1e is equally active by ip $(43.4 \%)$ and po $(34.9 \%)$ administration while this does not apply for 1a. More chemistry is required to improve the efficiency of the 1a series in vivo.

2.8. Inhibition of the Development of $P$. falciparum Trophozoites by Compound 1c. The intraerythrocytic cycle of $P$. falciparum begins when infective form of the parasite invades an erythrocyte and it ends $48 \mathrm{~h}$ later when multiple new infective parasites escape from the host cell. In the meantime, Plasmodium has developed through ring (0-20 h postinvasion (p.i.)), trophozoite (20-36 h p.i.) and schizont (36-48 h p.i.) stages. Because trophozoite is the most active stage at digesting host cell hemoglobin, we assessed whether compound 1c might inhibit trophozoite development. As determined from doseresponse assays, compound 1c inhibits FcB1 trophozoite growth with a $0.90 \mu \mathrm{M} \mathrm{IC} \mathrm{IC}_{50}$ value and an estimated $5 \mu \mathrm{M}$ IC $_{100 m i n}$. Chloroquine $\mathrm{IC}_{50}$ and $\mathrm{IC}_{100}$ values on $\mathrm{FcB} 1$ trophozoites were $0.25 \mu \mathrm{M}$ and $2 \mu \mathrm{M}$, respectively. As shown in Figure 8, maturation of young trophozoites was dramatically altered in the presence of $5 \mu \mathrm{M}$ compound 1c (column 1c) or $5 \mu \mathrm{M}$ chloroquine (column CQ).

Figure 8. Compound 1c-Induced Inhibition of $P$. falciparum Trophozoite Development. ${ }^{a}$

Oh
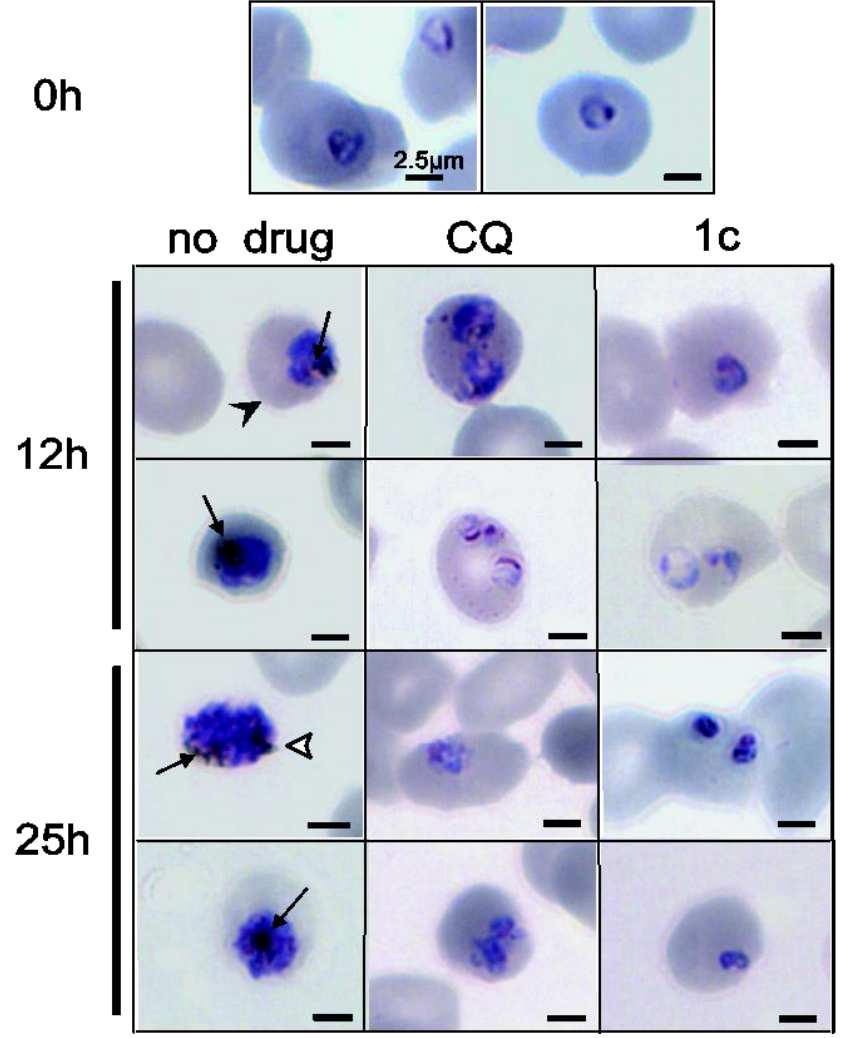

${ }^{a}$ Optical examination of compound 1c-induced inhibition of $P$. falciparum trophozoites was performed microscopically. Synchronized parasites at the trophozoite stage of the intraerythrocytic cycle (i.e. $16 \mathrm{~h}-21 \mathrm{~h}$ posterythrocyte invasion) were grown either in normal culture medium (no drug) or in culture medium supplemented with $5 \mu \mathrm{M}$ chloroquine (CQ) or $5 \mu \mathrm{M}$ compound 1c. Diff Quick-stained smears were prepared from aliquots of the cultures at different time points. Details from smears at $0 \mathrm{~h}$ (16-21 h-old parasites), $12 \mathrm{~h}$ (28-33 h-old parasites) and 25 $\mathrm{h}$ (41-46 h-old parasites) of incubation are presented. Hemozoin in the parasite food vacuole is indicated by an arrow. Black arrowhead: erythrocyte. Note the multinucleated parasite (empty arrowhead) after $25 \mathrm{~h}$ in normal culture (no drug). Scale bar: $2.5 \mu \mathrm{m}$. Photographs: Metamorph software, Power Point/Illustrator software. 
In both cases, a $12 \mathrm{~h}$ application prevented the parasite development and no hemozoin was seen in the food vacuole (Figure 8, 1c $12 \mathrm{~h}$, CQ $12 \mathrm{~h}$ ). Prolonged incubation with compound 1c led to parasite condensation and appearance of pycnotic forms (Figure 8, 1c 25 h) contrasting with the shapeless, uncondensed forms observed with chloroquine (Figure 8, CQ 25 h). Thus, our results show that compound $\mathbf{1 c}$ is inhibitory to trophozoite development and prevents the formation of hemozoin.

\section{Discussion}

The role of redox enzymes in allowing the establishment of a microenvironment for parasite development is well known. It is clinically validated by the observation made in hemoglobinopathies that increasing the oxidative stress in erythrocytes confers a milieu hostile for parasite development. Prevalence of glucose-6phosphate dehydrogenase (G6PDH) deficiency with 400 million people affected coincides with that of malaria with a very similar global distribution; this supports the so-called malaria protection hypothesis. ${ }^{25}$ In particular, the parasites do not develop well in G6PDH-deficient red blood cell $^{26}$ or in erythrocytes depleted in GR activity ${ }^{27}$ or in de novo biosynthesis of glutathione. ${ }^{28}$ At the biochemical level, G6PDH is the first enzyme of the pentose phosphate pathway (hexose monophosphate shunt, HMS in Figure 1) which provides the reducing power of the cells in the form of NADPH. As NADPH is the only reducing substrate for GR in erythrocytes, G6PDH deficiency in red blood cells can be regarded as a natural knock-down version of human GR. G6PDH deficiency is not a serious condition for humans but prevents a severe malaria attack since the low antioxidative capacity in the red blood cells makes the milieu hostile for Plasmodium. Consequently, rapid elimination of parasitized G6PDH-deficient cells from the circulation occurs by enhanced phagocytosis via complement activation. $^{29}$ This important observation was recently supported by data from Arese and Becker's groups. ${ }^{30}$ Human GR deficiency or druginduced GR inhibition may protect from malaria via inducing enhanced ring stage phagocytosis by macrophages rather than by impairing parasite growth directly. Thus, mimicking G6PDH deficiency by GR redox-cyclers and other GRtargeting compounds represents a challenge to design new preclinical candidates as antimalarial drugs. However, these drugs must not trigger hemolysis both in G6PDH-sufficient and G6PDHdeficient individuals. ${ }^{31}$ This essential prerequisite could be reached using a prodrug approach or an enzyme-drug bioactivation process. The most relevant examples of this strategy is being exemplified by the first-discovered synthetic antimalarial drug, methylene blue (MB), ${ }^{32}$ and in the present work, by our lead antimalarial 1,4naphthoquinones (NQ) $1 .^{33}$ These compounds lead to the killing of the malarial parasites, as reported here.

To develop this strategy the synthesis and the screening of more than 100 new menadione derivatives for antimalarial activity allowed us to characterize a new series of potent antimalarial 3benzylmenadione analogues 1 that are active both in vitro (in the low nM range against the tested $P$. falciparum $\mathrm{Dd} 2$ strain) as well as in vivo. The selected compounds displayed no observable toxic effects against the human KB and MRC-5 cell lines or in mice. These lead benzylNQ are proposed to be metabolized through a cascade of redox reactions, involving a heme-catalyzed benzylic oxidation reaction under the specific conditions found in the acidic vesicles/food vacuole of the parasites, and then by a highly effective GR-catalyzed reduction in the cytosol. This last step was confirmed to be essential for the bioactivation of the 3-benzylmenadione series since GR inactivation by a potent suicide-substrate generated in the parasites led to the abolishment of the antimalarial activity of the parent difluorinated benzylNQ. From the mechanistic point of view, the benzoylNQ metabolites, in oxidized form, were shown to act as the most efficient subversive substrates of reduced GR described so far and, in reduced form, to convert metHb to $\mathrm{Hb}$. The reduced species of benzoylNQ are assumed to be transported through $\mathrm{Fe}^{\mathrm{III}}$ complexation into the food vacuole where the electrons are transferred to oxidants (heme and metHb). Subsequently, in oxidized forms, the benzoylNQ might be transported into the cytosol where they are reduced by the cytosolic GR (either from human erythrocyte or from the parasite) in a continuous redox cycle (Figure 2). This work provides a new strategy based on the particular situation of electrochemically active $P$. falciparum-infected erythrocytes in the presence of redox-cyclers, transported as charged species between two compartments, the anodic one for oxidation reactions (acidic vesicle/food vacuole network), and the cathodic one for reduction reactions (cytosol), possibly via iron complexation. ${ }^{11 \mathrm{~d}, 34}$ 
Starting with $P$. falciparum-infected red blood cells and glucose as energy source, the benzoylNQ were designed to serve as membrane-permeable redox mediators and a source of electrons to inhibit the trophozoite development. Noteworthy is the fact that no harm is expected from human GR subversive substrates in all other host cells containing a nucleus because of the high flux control in these cells, for instance by the de novo enzyme synthesis. Only host red blood cells which have no nucleus and no possibility to regulate the glutathione biosynthesis - can be sensitive to reversible glutathione reductase inhibitors. This distinct situation between red blood cells and other nucleated cells represent the Achilles' heel on which we cash in as the co-target of our drug design strategy.

A second reason to target the reduction of metHb is that the ferric form of hemoglobin is not capable of oxygen transport. A decreased oxygen carrying capacity of blood due to anemia is exacerbated by reduction in oxygen carrying capacity; this might proceed from even a modest concentration of metHb leading to an impaired supply of oxygen for the tissue. The reduction of met $\mathrm{Hb}\left(\mathrm{Fe}^{\mathrm{III}}\right)$ to $\mathrm{Hb}\left(\mathrm{Fe}^{\mathrm{II}}\right)$ is of great importance in the treatment of malaria. High levels of metHb are observed in non-parasitized human red blood cells during Plasmodium vivax infections, ${ }^{35 a}$ during Plasmodium yoelii nigeriensis infection in mouse erythrocytes, ${ }^{35 \mathrm{~b}}$ and also, in primaquine (PQ)- or dapsone-treated patients with G6PDH deficiency. ${ }^{36,37}$ In the case of PQ, methemoglobinemia was recently shown to result from the transfer of one electron both from iron of $\mathrm{Hb}$ and the metabolite of $\mathrm{PQ}, 5$-hydroxyPQ, to the $\pi^{*}$ orbital of $\mathrm{O}_{2}{ }^{38}$ This favors the formation of $\mathrm{H}_{2} \mathrm{O}_{2}$ and the accumulation of metHb. In the present work, a high benefit of our strategy originates from the fact that the expected metabolites generated from the lead benzylNQ are effective substrates of GR; thus, the product, the reduced benzoylNQ, redox-cycle metHb to $\mathrm{Hb}$. This is not the case of PQ and other 8aminoquinolines. Nevertheless, optimizing and developing our lead benzylNQ into preclinical candidates will involve several challenges concerning the pathophysiology of hemolysis in G6PDH patients. As there is no pharmacologically validated model today for hemolysis in G6PDHdeficient populations, we are setting up such a platform to determine and to predict any detrimental effects on G6PDH-deficient red blood cells from patients at risk.
In summary, the antimalarial 1,4naphthoquinones are proposed to act catalytically as redox-active biosensors that are cycled in and out the food vacuole in infected red blood cells, thereby oxidizing major intracellular reductants (like NADPH in the cytosol) and subsequently reducing the oxidants (hematin and metHb). Ultimately, the antimalarial 1,4-naphthoquinones are suggested to affect the redox equilibrium in the parasites, drowning the parasite in its own metabolic products. They will serve as lead compounds for further structural refinement with improved solubility and/or bioavailability.

In the long term, the results from our interdisciplinary approach will provide detailed insight into the understanding of how redoxcyclers interfere with the putative negative cooperativity of GR toward NADPH binding and how this property can be exploited for disulfide reductase-catalyzed drug bioactivation as a general concept to open a new perspective in medicinal chemistry. Mechanism of this putative negative cooperativity towards NADPH binding remains to be proved and orientates the future direction of our investigations.

\section{Experimental section}

4.1. Chemistry. Melting points were determined on a Büchi melting point apparatus and were not corrected. ${ }^{1} \mathrm{H}(300 \mathrm{MHz})$ and ${ }^{13} \mathrm{C}(75$ $\mathrm{MHz}$ ) NMR spectra were recorded on a Bruker DRX-300 spectrometer; chemical shifts were expressed in ppm relative to TMS; multiplicity is indicated as s (singlet), $\mathrm{d}$ (doublet), $\mathrm{t}$ (triplet), $\mathrm{q}$ (quartet), sep (septet), m (multiplet), cm (centered multiplet), dd (doublet of a doublet), dt (doublet of a triplet) and td (triplet of a doublet). $\mathrm{C}_{\mathrm{q}}$ indicates a quaternary carbon in the ${ }^{13} \mathrm{C}$ NMR assignation. ${ }^{19} \mathrm{~F} \quad \mathrm{NMR}$ was performed using 1,2difluorobenzene as external standard $(\delta=-139.0$ $\mathrm{ppm})$. Intensities in the IR spectra are indicated as vs (very strong), s (strong), m (medium), w (weak), b (broad). Elemental analyses were carried out at the Mikroanalytisches Laboratorium der Chemischen Fakultät der Universität Heidelberg. EI MS and CI MS were recorded at facilities of the Institut für Organische Chemie der Universität Heidelberg. Analytical TLC was carried out on pre-coated Sil G-25 UV UV $_{24}$ plates from Macherey\&Nagel. Flash chromatography was performed using silica gel G60 (230-400 mesh) from Macherey\&Nagel.

General Procedure for the Silver-Catalyzed Radical Decarboxylation Reactions of 1,4 
Naphthoquinones with Carboxylic Acids. A solution of menadione or plumbagin $(5.81 \mathrm{mmol})$ and of phenylacetic acid derivative $(11.58 \mathrm{mmol})$ in $52.5 \mathrm{~mL}$ acetonitrile and $17.5 \mathrm{~mL}$ water was heated to $85^{\circ} \mathrm{C} . \mathrm{AgNO}_{3}(90 \mathrm{mg}, 0.58 \mathrm{mmol})$ was added. $\left(\mathrm{NH}_{4}\right)_{2} \mathrm{~S}_{2} \mathrm{O}_{8}(1.72 \mathrm{~g}, 7.54 \mathrm{mmol})$ in $15 \mathrm{~mL}$ acetonitrile and $5 \mathrm{~mL}$ water was added dropwise over a period of 45 minutes and then heated at reflux for two hours. The acetonitrile was removed in vacuo. The aqueous phase was extracted with dichloromethane ( 4 x $10 \mathrm{~mL})$, dried over $\mathrm{MgSO}_{4}$ and purified by flash-chromatography. 2-(4bromobenzyl)-3-methylnaphthalene-1,4-dione 1a. As starting materials for the radical decarboxylation reaction menadione and 4bromophenylacetic acid were used. After chromatography on silica gel (PE : $\mathrm{CH}_{2} \mathrm{Cl}_{2}=1: 1$, UV), $3.10 \mathrm{~g}$ (9.12 mmol, $78 \%$ yield) of $1 \mathrm{a}$ were isolated as a yellow solid. m.p. $121-122{ }^{\circ} \mathrm{C} ;{ }^{1} \mathrm{H}$ NMR (300 MHz, $\left.\mathrm{CDCl}_{3}\right): \delta$ 8.03-8.10 $(\mathrm{m}, 2 \mathrm{H})$, 7.66-7.71 (m, 2H), $7.36\left(\mathrm{dt},{ }^{3} J=8.46 \mathrm{~Hz},{ }^{4} \mathrm{~J}=\right.$ $1.95 \mathrm{~Hz}, 2 \mathrm{H}), 7.09\left(\mathrm{~d},{ }^{3} J=8.53 \mathrm{~Hz}, 2 \mathrm{H}\right), 3.96(\mathrm{~s}$, 2H), $2.22(\mathrm{~s}, 3 \mathrm{H}) ;{ }^{13} \mathrm{C}$ NMR $\left(75 \mathrm{MHz}, \mathrm{CDCl}_{3}\right): \delta$ $185.20\left(\mathrm{C}_{\mathrm{q}}\right), 184.54\left(\mathrm{C}_{\mathrm{q}}\right), 144.75\left(\mathrm{C}_{\mathrm{q}}\right), 144.57\left(\mathrm{C}_{\mathrm{q}}\right)$, $137.06\left(\mathrm{C}_{\mathrm{q}}\right), 133.58(\mathrm{CH}), 132.08\left(\mathrm{C}_{\mathrm{q}}\right), 131.94$ $\left(\mathrm{C}_{\mathrm{q}}\right), 131.71(\mathrm{CH}), 130.32(\mathrm{CH}), 126.50(\mathrm{CH})$, $126.35(\mathrm{CH}), 120.31\left(\mathrm{C}_{\mathrm{q}}\right), 31.93\left(\mathrm{CH}_{2}\right), 13.31$ $\left(\mathrm{CH}_{3}\right)$; IR (KBr): v=3449 (b, w), 3068 (w), 2962 (w), 1661 (vs), 1624 (m), 1618 (m), 1594 (s), 1486 (s), 1376 (m), 1332 (s), 1315 (s), 1294 (vs), 1071 (m), $1010(\mathrm{~s}), 971(\mathrm{w}), 815(\mathrm{~m}), 787(\mathrm{~s}), 730(\mathrm{~m})$, $702(\mathrm{~m}), 629(\mathrm{w}), 426 \mathrm{~cm}^{-1}(\mathrm{w})$; EI MS $(70 \mathrm{eV}$, $\mathrm{m} / \mathrm{z}(\%)): 340.1\left([\mathrm{M}]^{+}, 13\right), 325.0(100), 246.1(63)$, 215.1 (41), 202.1 (49), 128.1 (72), 76.0 (74); elemental analysis calcd. (\%) for $\mathrm{C}_{18} \mathrm{H}_{13} \mathrm{BrO}_{2}$ : C 63.36, H 3.84; found. C 63.02, H 3.84. 2-(4Bromobenzyl)-3-(Difluoromethyl)Naphthalene1,4-Dione 7a. As starting materials for the radical decarboxylation reaction difluoromenadione and 4-bromophenylacetic acid were used. After chromatography on silica gel ( $\mathrm{PE}: \mathrm{CH}_{2} \mathrm{Cl}_{2}=1: 1$, UV), $132 \mathrm{mg}$ ( $0.35 \mathrm{mmol}, 73 \%$ yield) of $7 \mathbf{a}$ were isolated as a yellow solid. m.p. 103-104 ${ }^{\circ} \mathrm{C} ;{ }^{1} \mathrm{H}$ NMR $\left(300 \mathrm{MHz}, \mathrm{CDCl}_{3}\right): \delta 8.07-8.13(\mathrm{~m}, 1 \mathrm{H})$, 7.99-8.05 (m, 1H), 7.70-7.79 (m, 2H), $7.36\left(\mathrm{~d},{ }^{3} J=\right.$ $8.46 \mathrm{~Hz}, 2 \mathrm{H}), 7.24\left(\mathrm{t},{ }^{1} J=53.87 \mathrm{~Hz}, 1 \mathrm{H}, \mathrm{CHF}_{2}\right)$, $7.18\left(\mathrm{~d},{ }^{3} \mathrm{~J}=8.42 \mathrm{~Hz}, 2 \mathrm{H}\right), 4.19(\mathrm{~s}, 2 \mathrm{H}),{ }^{13} \mathrm{C}$ NMR $\left(75 \mathrm{MHz}, \mathrm{CDCl}_{3}\right): \delta 184.38\left(\mathrm{C}_{\mathrm{q}}\right), 182.79\left(\mathrm{C}_{\mathrm{q}}\right)$, $149.21\left(\mathrm{C}_{\mathrm{q}}\right), 136.03\left(\mathrm{C}_{\mathrm{q}}\right), 134.41(\mathrm{CH}), 131.76$ $\left(\mathrm{C}_{\mathrm{q}}\right), 131.63(\mathrm{CH}), 130.89(\mathrm{CH}), 126.87(\mathrm{CH})$, $126.54(\mathrm{CH}), 120.67\left(\mathrm{C}_{\mathrm{q}}\right), 110.45\left(\mathrm{CHF}_{2},{ }^{1} \mathrm{~J}=\right.$ $239.85 \mathrm{~Hz}), 31.66\left(\mathrm{CH}_{2}\right)$; IR ( $\left.\mathrm{KBr}\right): \mathrm{v}=3436(\mathrm{~b}, \mathrm{w})$, $3100(\mathrm{w}), 3076(\mathrm{w}), 3049(\mathrm{w}), 3018(\mathrm{w}), 2936(\mathrm{w})$, 1672 (vs), 1657 (vs), 1625 (s), 1594 (s), 1487 (vs),
1406 (m), 1329 (s), 1297 (vs), 1181 (m), 1123 (s), 1082 (s), 1071 (m), 1035 (vs), 1013 (s), 876 (m), $831(\mathrm{~s}), 788(\mathrm{~s}), 733(\mathrm{~s}), 713(\mathrm{~m}), 535 \mathrm{~cm}^{-1}(\mathrm{~m})$; EI MS (70 eV, $\mathrm{m} / z(\%)): 377.1\left([\mathrm{M}]^{+}, 21\right), 325.1(11)$, 257.1 (10), 169.0 (100), 90.1 (18); elemental analysis calcd. (\%) for $\mathrm{C}_{18} \mathrm{H}_{11} \mathrm{BrF}_{2} \mathrm{O}_{2}: \mathrm{C} 57.32, \mathrm{H}$ 2.94; found: C 57.01, H 3.12.

General Procedure for the Oxidation of Benzyl Derivatives to the corresponding Benzoyl Derivatives. $\mathrm{H}_{5} \mathrm{IO}_{6}(1.40 \mathrm{~g}, 6.16 \mathrm{mmol})$ was dissolved in $25 \mathrm{~mL}$ acetonitrile by vigorous stirring and then $\mathrm{CrO}_{3}(17.6 \mathrm{mg}, 0.18 \mathrm{mmol})$ was dissolved into the mixture to give an orange solution. The benzyl-derivative $(0.88 \mathrm{mmol})$ was added to the above solution with stirring. The solution turned to an orange suspension within a few seconds that turned yellow after a few minutes. The solution was stirred at $\mathrm{rt}$ until all starting material was consumed (TLC control). The solvent was removed in vacuo and the residue was purified by flash-chromatography to give the corresponding benzoyl-derivative. 2-(4Bromobenzoyl)-3-Methylnaphthalene-1,4-

Dione 3a. As starting material 1a was used. After chromatography on silica gel ( $\mathrm{PE}: \mathrm{CH}_{2} \mathrm{Cl}_{2}=1: 3$, UV), $133 \mathrm{mg}$ ( $0.38 \mathrm{mmol}, 43 \%$ yield) of $\mathbf{3 a}$ were isolated as a yellow solid. m.p. $170-171^{\circ} \mathrm{C} ;{ }^{1} \mathrm{H}$ NMR $\left(300 \mathrm{MHz}, \mathrm{CDCl}_{3}\right): \delta 8.14-8.17(\mathrm{~m}, 1 \mathrm{H})$, 8.03-8.06 (m, 1H), 7.73-7.81 (m, 4H), $7.64\left(\mathrm{t},{ }^{3} \mathrm{~J}=\right.$ $2.08 \mathrm{~Hz}, 1 \mathrm{H}), 7.61\left(\mathrm{t},{ }^{3} \mathrm{~J}=1.95 \mathrm{~Hz}, 1 \mathrm{H}\right), 2.05(\mathrm{~s}$, $\left.\mathrm{CH}_{3}\right) ;{ }^{13} \mathrm{C}$ NMR (75 MHz, $\left.\mathrm{CDCl}_{3}\right): \delta 192.72\left(\mathrm{C}_{\mathrm{q}}\right)$, $184.63\left(\mathrm{C}_{\mathrm{q}}\right), 183.32\left(\mathrm{C}_{\mathrm{q}}\right), 144.30\left(\mathrm{C}_{\mathrm{q}}\right), 143.85\left(\mathrm{C}_{\mathrm{q}}\right)$, $134.49\left(\mathrm{C}_{\mathrm{q}}\right), 134.30(\mathrm{CH}), 134.19(\mathrm{CH}), 132.48$ $(\mathrm{CH}), 131.87\left(\mathrm{C}_{\mathrm{q}}\right), 131.49\left(\mathrm{C}_{\mathrm{q}}\right), 130.52(\mathrm{CH})$, $130.01\left(\mathrm{C}_{\mathrm{q}}\right), 126.78(\mathrm{CH}), 126.44(\mathrm{CH}), 13.60$ $\left(\mathrm{CH}_{3}\right)$; IR (KBr): v=3442 (b, m), 1669 (vs), 1653 (vs), 1627 (vs), 1586 (m), 1568 (m), 1398 (m), 1378 (m), 1329 (s), 1291 (vs), 1272 (s), 1241 (m), $1176(\mathrm{~m}), 1069$ (m), $1011(\mathrm{~m}), 978$ (s), $864(\mathrm{~m})$, $784(\mathrm{~s}), 722(\mathrm{~m}), 692 \mathrm{~cm}^{-1}(\mathrm{~m})$; EI MS $(70 \mathrm{eV}, \mathrm{m} / \mathrm{z}$ (\%)): $353.9\left([\mathrm{M}]^{+}, 41\right), 275.0$ (100), 182.9 (71), 115.0 (50), 76.0 (41); elemental analysis calcd. (\%) for $\mathrm{C}_{18} \mathrm{H}_{11} \mathrm{BrO}_{3}$ : C 60.87, H 3.12, $\mathrm{Br} 22.50$; found: $\mathrm{C} \quad 60.96, \mathrm{H} \quad 3.24, \mathrm{Br} 22.60$. 2-(4Bromobenzoyl)-3-(Difluoromethyl)-naphthalene-1,4-Dione 8a. As starting material 7a was used. $40 \mathrm{mg}$ ( $0.10 \mathrm{mmol}, 78 \%$ yield $)$ of $\mathbf{8 a}$ were isolated as a yellow solid. m.p. $=135-137^{\circ} \mathrm{C} ;{ }^{1} \mathrm{H}$ NMR $\left(300 \mathrm{MHz}, \mathrm{CDCl}_{3}\right): \delta 8.20\left(\mathrm{dd}, 1 \mathrm{H},{ }^{3} \mathrm{~J}=7,1 \mathrm{~Hz}\right.$, $\left.{ }^{4} J=1,9 \mathrm{~Hz}\right), 8.10\left(\mathrm{dd}, 1 \mathrm{H},{ }^{3} J=7,2 \mathrm{~Hz},{ }^{4} J=1,8 \mathrm{~Hz}\right)$, 7.84-7.89 (m, 2H), $7.75\left(\mathrm{~d}, 2 \mathrm{H},{ }^{3} \mathrm{~J}=8,6 \mathrm{~Hz}\right), 7.65(\mathrm{~d}$, $\left.2 \mathrm{H},{ }^{3} \mathrm{~J}=8,6 \mathrm{~Hz}\right), 6.90\left(\mathrm{t}, 1 \mathrm{H},{ }^{2} \mathrm{~J}=53,3 \mathrm{~Hz}\right) ;{ }^{13} \mathrm{C} \mathrm{NMR}$ $\left(75 \mathrm{MHz}, \mathrm{CDCl}_{3}\right): \delta 189.86\left(\mathrm{C}_{\mathrm{q}}\right), 183.38\left(\mathrm{C}_{\mathrm{q}}\right)$, $182.44\left(\mathrm{C}_{\mathrm{q}}\right), 144.38\left(\mathrm{C}_{\mathrm{q}}\right), 135.30\left(\mathrm{C}_{\mathrm{q}}\right), 135.28$ $(\mathrm{CH}), 135.18(\mathrm{CH}), 134.34\left(\mathrm{C}_{\mathrm{q}}\right), 132.35(\mathrm{CH})$, 
$131.91(\mathrm{CH}), \quad 131.67(\mathrm{CH}), 130.91\left(\mathrm{C}_{\mathrm{q}}\right), 130.42$ $(\mathrm{CH}), 130.04\left(\mathrm{C}_{\mathrm{q}}\right), 126.91(\mathrm{CH}), 126.87(\mathrm{CH})$, $125.70\left(\mathrm{C}_{\mathrm{q}}\right), 110.02\left(\mathrm{CHF}_{2}\right)$; EI MS $(70 \mathrm{eV}, \mathrm{m} / \mathrm{z}$ (\%)): 391.9 ([M]+, 26), 326.9 (35), 200.0 (40), 182.9 (100), 154.9 (30), 104.0 (26), 76.1 (25); elemental analysis calcd. (\%) for $\mathrm{C}_{18} \mathrm{H}_{9} \mathrm{BrF}_{2} \mathrm{O}_{3}$ : C 55.27; H 2.32, found: C 54.92, H 2.85 .

2-(Difluoromethyl)-1,4-Dimethoxynaphtha-

lene 19. The reaction was conducted in a Teflon ${ }^{\circledR}$ bottle under $\mathrm{N}_{2}$-atmosphere. To a solution of 750 $\mathrm{mg}$ (3.47 mmol) 1,4-dimethoxy-naphthalene-2carbaldehyde in $10 \mathrm{~mL}$ dry $\mathrm{CH}_{2} \mathrm{Cl}_{2}$ was added 775 $\mu \mathrm{L}$ (950 mg, $5.90 \mathrm{mmol})$ DAST and $10 \mu \mathrm{L}(0.17$ mmol) ethanol at $0{ }^{\circ} \mathrm{C}$. The reaction mixture was stirred for $1 \mathrm{~h}$ at this temperature and then heated overnight to $40{ }^{\circ} \mathrm{C}$. To run the reaction to completion another $140 \mu \mathrm{L}$ DAST was added followed by incubation at $40{ }^{\circ} \mathrm{C}$ for additional $5 \mathrm{~h}$. $10 \mathrm{~mL}$ of saturated $\mathrm{NaHCO}_{3}$-solution was added in small portions to quench the reaction. The organic phase was separated, the aqueous phase was extracted with $\mathrm{CH}_{2} \mathrm{Cl}_{2}(2 \times 20 \mathrm{~mL})$, dried over $\mathrm{MgSO}_{4}$ and purified by flash-chromatography on silica gel (PE : $\left.\mathrm{CH}_{2} \mathrm{Cl}_{2}=1: 1, \mathrm{UV}\right)$ to give $723 \mathrm{mg}$ of 19 (3.03 mmol, $88 \%)$ of an almost colorless solid. m.p. $44-46^{\circ} \mathrm{C} ;{ }^{1} \mathrm{H}$ NMR $\left(300 \mathrm{MHz}, \mathrm{CDCl}_{3}\right)$ : $\delta$ 8.25-8.30 (m, $1 \mathrm{H}), 8.06-8.11(\mathrm{~m}, 1 \mathrm{H}), 7.53-7.62$ $(\mathrm{m}, 2 \mathrm{H}), 7.16\left(\mathrm{t},{ }^{1} J=55.8 \mathrm{~Hz}, 1 \mathrm{H}, \mathrm{CHF}_{2}\right), 6.90(\mathrm{~s}$, 1H), 4.02 (s, 3H), $3.97(\mathrm{~s}, 3 \mathrm{H}) ;{ }^{13} \mathrm{C}$ NMR $(75 \mathrm{MHz}$, $\left.\mathrm{CDCl}_{3}\right): \delta 152.3\left(\mathrm{C}_{\mathrm{q}}\right), 148.5\left(\mathrm{C}_{\mathrm{q}}\right), 127.9\left(\mathrm{C}_{\mathrm{q}}\right)$, $126.9(\mathrm{CH}), 126.7(\mathrm{CH}), 122.6\left(\mathrm{C}_{\mathrm{q}}\right), 122.5(\mathrm{CH})$, $122.2\left(\mathrm{C}_{\mathrm{q}}\right), 122.0(\mathrm{CH}), 111.7\left(\mathrm{t},{ }^{1} J=235 \mathrm{~Hz}\right.$, $\left.\mathrm{CHF}_{2}\right), 98.6(\mathrm{CH}), 63.8\left(\mathrm{CH}_{3}\right), 55.5\left(\mathrm{CH}_{3}\right) ;{ }^{19} \mathrm{~F}$ NMR $\left(\mathrm{CDCl}_{3}\right): \delta-112.37\left(\mathrm{~d},{ }^{1} J=55.8 \mathrm{~Hz}\right) ; \mathrm{EI}$ MS (70 eV, $m / z(\%)): 238.07$ ([M] $\left.]^{+}, 95\right), 223.0$ (100); elemental analysis calcd. (\%) for $\mathrm{C}_{13} \mathrm{H}_{12} \mathrm{~F}_{2} \mathrm{O}_{2}$ : C 65.54, H 5.08; found: C 65.39, $\mathrm{H}$ 5.20 .

2-(Difluoromethyl)Naphthalene-1,4-Dione (or Difluoromenadione). $500 \mathrm{mg}(2.10 \mathrm{mmol}) 2$ difluoromethyl-1,4-dimethoxy-naphthalene 19 was dissolved in $10 \mathrm{~mL} \mathrm{CH}_{3} \mathrm{CN}$ and a solution of 3.45 $\mathrm{g}(6.30 \mathrm{mmol}) \mathrm{CAN}$ in $8 \mathrm{~mL} \mathrm{H}_{2} \mathrm{O}$ was added. The reaction mixture was stirred for $15 \mathrm{~min}$ at room temperature, the acetonitrile was removed in vacuo, the product was extracted with $\mathrm{CH}_{2} \mathrm{Cl}_{2}(5 \mathrm{x}$ $10 \mathrm{~mL}$ ), dried over $\mathrm{MgSO}_{4}$ and purified by flashchromatography on silica gel ( $\mathrm{PE}: \mathrm{CH}_{2} \mathrm{Cl}_{2}=1: 1$, $\mathrm{UV)}$ to give $405 \mathrm{mg}$ difluoromenadione as a yellow solid (1.95 mmol, 93\%). m.p. $74^{\circ} \mathrm{C} ;{ }^{1} \mathrm{H}$ NMR $\left(300 \mathrm{MHz}, \mathrm{CDCl}_{3}\right): \delta 8.07-8.15(\mathrm{~m}, 2 \mathrm{H})$, $7.76-7.83(\mathrm{~m}, 2 \mathrm{H}), 7.19(\mathrm{~m}, 1 \mathrm{H}), 6.83\left(\mathrm{t},{ }^{1} J=\right.$ $\left.53.9 \mathrm{~Hz}, \mathrm{CHF}_{2}, 1 \mathrm{H}\right) ;{ }^{13} \mathrm{C} \mathrm{NMR}\left(75 \mathrm{MHz}, \mathrm{CDCl}_{3}\right)$ : $\delta 183.9\left(\mathrm{C}_{\mathrm{q}}\right), 182.4\left(\mathrm{C}_{\mathrm{q}}\right), 140.4\left(\mathrm{t},{ }^{2} J=21.2 \mathrm{~Hz}\right.$, $\left.\mathrm{C}_{\mathrm{q}}\right), 135.1(\mathrm{CH}), 134.9(\mathrm{CH}), 134.3(\mathrm{CH}), 134.2$
$(\mathrm{CH}), 131.6\left(\mathrm{C}_{\mathrm{q}}\right), 131.3\left(\mathrm{C}_{\mathrm{q}}\right), 126.4(\mathrm{CH}), 109.2(\mathrm{t}$, $\left.{ }^{1} J=240.4 \mathrm{~Hz}, \mathrm{CHF}_{2}\right) ;{ }^{19} \mathrm{~F}-\mathrm{NMR}\left(\mathrm{CDCl}_{3}\right) \delta-$ $123.85\left(\mathrm{~d},{ }^{1} J=53.9 \mathrm{~Hz}\right)$; EI MS $(70 \mathrm{eV}, \mathrm{m} / z(\%))$ $208.02([\mathrm{M}+], 100)$ calc. 208.03; elemental analysis calcd. (\%) for $\mathrm{C}_{11} \mathrm{H}_{6} \mathrm{~F}_{2} \mathrm{O}_{2}: \mathrm{C} 63.47, \mathrm{H}$ 2.91; found: C 63.58, H 3.02 .

4.2. In Vitro Antiparasitic Bioassays. $P$. falciparum in vitro culture was carried out using standard protocols ${ }^{39}$ with modifications. ${ }^{12 \mathrm{~b}}$ Drug susceptibility of $P$. falciparum was studied using a modified method ${ }^{18}$ of the protocol described previously for the ${ }^{3} \mathrm{H}$-hypoxanthine incorporationbased assay. ${ }^{19}$ All assays included CQ diphosphate (Sigma, UK) as standard and control wells with untreated infected and uninfected erythrocytes. $\mathrm{IC}_{50}$ values were derived by sigmoidal regression analysis (Microsoft $x l \mathrm{fit}^{\mathrm{TM}}$ ). Determination of $\mathrm{IC}_{50}$ Values Against Dd2 P. falciparum Strain. The $\mathrm{IC}_{50}$ was tested by standard in vitro antiproliferation assays based on the ${ }^{3} \mathrm{H}-$ hypoxanthine incorporation. ${ }^{19}$ Infected erythrocytes in ring stage $(0.5 \%$ parasitemia, $2.5 \%$ hematocrit) in 96-well plates were exposed to the compounds for $48 \mathrm{~h}$ and then to radioactive hypoxanthine for $24 \mathrm{~h}$. The amount of radioactivity in precipitable material served as an index of cell proliferation. Chloroquine was added as reference and displayed an $\mathrm{IC}_{50}$ value of 110 $\mathrm{nM}$.

4.3. Enzymes. Recombinant human and Plasmodium falciparum glutathione reductases were purified as previously reported. ${ }^{32 a, 40}$ One unit of GR activity is defined as the consumption of 1 $\mu$ mol NADPH per min $\varepsilon_{340 \mathrm{~nm}}=6.22 \mathrm{mM}^{-1} \mathrm{~cm}^{-1}$ ) under conditions of substrate saturation. The enzyme stock solutions used for kinetic determinations were $>98 \%$ pure as judged from silver stained SDS-PAGE and had specific activities of $200 \mathrm{U} / \mathrm{mg}$ (human GR) and $120 \mathrm{U} / \mathrm{mg}$ (P. falciparum $\mathrm{GR}$ ). All other reagents were of the highest available purity and were purchased from Biomol, Boehringer, and Sigma. Glutathione Disulfide Reduction Assays. The standard assay was conducted at $25^{\circ} \mathrm{C}$ in a $1 \mathrm{~mL}$-cuvette. The assay mixture contained $100 \mu \mathrm{M}$ NADPH and 1 $\mathrm{mM}$ GSSG in GR buffer (100 mM potassium phosphate buffer, $200 \mathrm{mM} \mathrm{KCl}, 1 \mathrm{mM}$ EDTA, $\mathrm{pH}$ 6.9). $\mathrm{IC}_{50}$ values were evaluated in duplicate in the presence of seven inhibitor concentrations ranging from 0 to $100 \mu \mathrm{M}$. Inhibitor stock solutions were prepared in $100 \%$ DMSO. $1 \%$ DMSO concentration was kept constant in the assay cuvette. The reaction was started by adding enzyme ( $8 \mathrm{mU}$ human $\mathrm{GR}, 6.5 \mathrm{mU}$ P. falciparum GR) and initial rates of NADPH oxidation were 
monitored at $340 \mathrm{~nm}\left(\varepsilon_{340 \mathrm{~nm}}=6.22 \mathrm{mM}^{-1} \mathrm{~cm}^{-1}\right)$. Inhibition of GSSG reduction by $\mathbf{3 f}$ was measured as a function of substrate concentration, and the data were fitted by using a nonlinear regression analysis software (Kaleidagraph) to the equation for uncompetitive inhibition. ${ }^{11 a}$ 1,4-Naphthoquinone Reductase Activity of $P$. falciparum Glutathione Reductase. The reduction assay mixture consisted of $100 \mathrm{mM}$ potassium phosphate buffer $\mathrm{pH} 6.9,200 \mathrm{mM} \mathrm{KCl}, 1 \mathrm{mM}$ EDTA and $100 \mu \mathrm{M}$ NADPH in a total volume of 1 $\mathrm{mL}$. 1,4-Naphthoquinone reductase activity was determined by recording the initial velocities in the presence of increasing naphthoquinone concentrations $(0-300 \mu \mathrm{M})$. The 1,4naphthoquinone was first dissolved in DMSO, and a final $1 \%$ DMSO concentration was kept constant in the 1,4-naphthoquinone reductase assay. For the determination of $K_{\mathrm{m}}$ and $V_{\max }$ values, the steady-state rates were fitted by using nonlinear regression analysis software (Kaleidagraph) to the Michaelis-Menten equation. From these values, the turnover number $k_{\text {cat }}$ and the catalytic efficiency $k_{\mathrm{cat}} / K_{\mathrm{m}}$ were calculated.

\subsection{Time-Dependent Inactivation of} Glutathione Reductases by Difluoromenadione, 7a and 8a. For determining the rate constants of human GR inactivation, the residual GR activity was monitored over time by following an incubation protocol. All reaction mixtures (final volume of $50 \mu \mathrm{L}$ ) contained $160 \mu \mathrm{M} \mathrm{NADPH}$, varying inhibitor concentrations $(0-5 \mu \mathrm{M}$ in the human GR assay; $0-50 \mu \mathrm{M}$ in the $P$. falciparum GR assay), GR (6.85 pmol human GR; 21 pmol $P$. falciparum GR), $2 \%$ DMSO in GR buffer at $25^{\circ} \mathrm{C}$. At different time points ( $<10 \mathrm{~min}) 5 \mu \mathrm{L}$-aliquots of each reaction mixture were removed and the residual activity was measured in the standard GSSG reduction assay at $25^{\circ} \mathrm{C}(1 \mathrm{mM} \mathrm{GSSG}$ and $100 \mu \mathrm{M}$ NADPH). $2 \%$ DMSO was used in control assays.

4.5. Methemoglobin Reduction in the Presence of BenzoylNQ 3a or 3d, or MB upon Reduction by the NADPH-GR System. In an Eppendorf tube containing $6.4 \mathrm{mg}$ human metHb dissolved in $885 \mu \mathrm{L}$ GR buffer $(47 \mathrm{mM}$ potassium phosphate buffer $\mathrm{pH} 6.9,200 \mathrm{mM} \mathrm{KCl}, 100 \mathrm{mM}$ EDTA), $10 \mu \mathrm{L} 20 \mathrm{mM}$ 3a dissolved in DMSO and $100 \mu \mathrm{L}$ NADPH dissolved in GR buffer were added. The reaction was started by the addition of $5 \mu \mathrm{L}$ human GR $(1.06 \mu \mathrm{mol})$ and then incubated at $37{ }^{\circ} \mathrm{C}$. In a $1 \mathrm{~mL}$ cuvette $20 \mu \mathrm{L}$ of the reaction mixture was diluted with $980 \mu \mathrm{L}$ GR buffer. UVVis spectral absorption changes induced by the benzoylNQ 3d, or the controls $\mathrm{MB}$ or $\mathrm{CQ}$, on methemoglobin chromophore were monitored from $300 \mathrm{~nm}$ to $700 \mathrm{~nm}$ on a Cary 50 (Varian) spectrophotometer maintained at $37^{\circ} \mathrm{C}$ after 0,5 , 10,20 and $30 \mathrm{~min}$ incubation time. The final concentrations in the reaction mixture were 100 $\mu \mathrm{M}$ metHb, $200 \mu \mathrm{M}$ benzoylNQ or MB, $400 \mu \mathrm{M}$ $\mathrm{NADPH}$ and $1.06 \mu \mathrm{mol} \mathrm{hGR}$, final DMSO concentration $1 \%, 37^{\circ} \mathrm{C}$. No metHb reduction was observed in the presence of CQ, which was used as negative control. Direct Methemoglobin Reduction in the Presence of the 3-BenzoylDihydronaphthoquinone 20. The UV-Vis spectral absorption changes induced by $40 \mu \mathrm{M}$ dihydronaphthoquinone 20 on $2 \mu \mathrm{M}$ methemoglobin chromophore were directly monitored in the cuvette from $250 \mathrm{~nm}$ to $550 \mathrm{~nm}$ on a Cary 300 (Varian) spectrophotometer maintained at $37.5^{\circ} \mathrm{C}$ by the flow of a Lauda E200 thermostat. The Scanning Kinetics application in FLWinLab software was used to monitor the spectral changes versus time with the following instrumental parameters: spectral window: 250$550 \mathrm{~nm}$; number of cycles: 30 ; cycle time: $45 \mathrm{~s}$; scanning rate: $200 \mathrm{~nm} / \mathrm{min}$; interval: $1 \mathrm{~nm}$.

4.6. Evaluation of Cytotoxicity of the Different Drugs Against Human Cell Lines. Evaluation of the Cytotoxicity Against Human KB Cells. Cytotoxicity on human KB cells (human oral pharyngeal carcinoma) was evaluated using the resazurin (Alamar Blue) assay as described. ${ }^{18}$ The positive control drug was podophyllotoxin (Sigma). IC $_{50}$ values were calculated compared to blanks and untreated controls. Evaluation of the Cytotoxicity Against Human MRC-5 cells. Human MRC- $5_{\text {Sv2 }}$ cells are cultured in Earl's $\mathrm{MEM}+5 \% \mathrm{FCSi}$. Assays are performed in 96well microtiter plates, each well containing about $10^{4}$ cell/well. After 3 days incubation, cell viability is assessed fluorimetrically after addition of resazurin and fluorescence is measured $\left(\lambda_{\text {ex }} 550\right.$ $\left.\mathrm{nm}, \lambda_{\mathrm{em}} 590 \mathrm{~nm}\right) .{ }^{18}$ The results are expressed as $\%$ reduction in cell growth/viability compared to untreated control wells and $\mathrm{IC}_{50}$ is determined. Compounds are tested at 5 concentrations (64-14$4-1-0.25 \mu \mathrm{M}$ or $\mathrm{mg} / \mathrm{mL}$ ). When the $\mathrm{IC}_{50}$ is lower than $4 \mu \mathrm{g} / \mathrm{mL}$ or $\mu \mathrm{M}$, the compound is classified as toxic.

4.7. Determination of \% Parasitemia in CD1 Mice. The in vivo tests in the mouse model were done according to a standard protocol. ${ }^{41}$ Compounds were tested in the ANKA $P$. berghei model by using the 4-day suppressive test, as indicated by Peters, and using chloroquine as a positive control. Briefly, naive $18-20-\mathrm{g}$ CD1 mice were infected intravenously with $210^{6}$ parasitized 
red cells on day +0 . For administration, compounds were freshly prepared in $10 \%$ DMSO in sterile phosphate-buffered saline the day of use. Two hours post-infection mice received the first treatment by the intraperitoneal route. Mice were further treated on days $+1-3$. Blood films from tail blood were prepared on day +4 , and parasitemia was determined by microscopic examination of Giemsa-stained blood films. Compounds were tested with a daily dose of 50 or $30 \mathrm{mg} / \mathrm{kg}$ by the intraperitoneal or oral route. Chloroquine treatment p.o. at $10 \mathrm{mg} / \mathrm{kg} / \mathrm{day}$ was included as a positive control and resulted in complete inhibition (data not shown). Intraperitoneous administrations of CQ have shown similar activity (98.9\% inhibition at $10 \mathrm{mg} / \mathrm{kg}$ i.p). Mice were treated and levels of parasitemia determined as described.

4.8. Morphological examination of $P$. falciparum trophozoite development inhibition by compound 1c. The FcB1 strain of $P$. falciparum was routinely grown in human erythrocytes and RPMI medium supplemented with $8 \%$ heat-inactivated human plasma under a $91 \% \mathrm{~N}_{2}, 6 \% \mathrm{O}_{2}$ and $3 \% \mathrm{CO}_{2}$ atmosphere. Parasites were synchronized on a $0-5 \mathrm{~h}$ time window by successive Plasmion ${ }^{\circledR 2}$ and sorbitol ${ }^{43}$ treatments. Dose-response assay based upon $\left[{ }^{3} \mathrm{H}\right]-$ hypoxanthine incorporation by growing parasites ${ }^{19}$ was used to determine the inhibitory concentrations of compound 1c. Shortly, 16h-21hold parasites (trophozoites) were incubated for $48 \mathrm{~h}$ in the presence of decreasing concentrations of compound $1 \mathrm{c}$ and $0.25 \mu \mathrm{Ci}\left[{ }^{3} \mathrm{H}\right]$-hypoxanthine. $\mathrm{IC}_{50}$ and $\mathrm{IC}_{100 \mathrm{~min}}$ values were determined from the resulting dose-response curves; they correspond to the drug concentration required to observe 50 and $100 \%$ of the inhibition of the parasitic growth, respectively (min means minimal drug concentration). For analysis of compound 1cinduced morphological alterations, trophozoites (16h-21h-old) were grown for $25 \mathrm{~h}$ at $1 \%$ parasitemia and $2 \%$ hematocrit in culture medium supplemented with $5 \mu \mathrm{M}$ ( $\left(\mathrm{IC}_{100 \mathrm{~min}}\right)$ compound 1 or $5 \mu \mathrm{M}$ chloroquine. Control for normal growth was in culture medium alone. Diff Quick-stained smears were made every two hours during $12 \mathrm{~h}$ and then after $25 \mathrm{~h}$, and were analyzed by optical examination.

Acknowledgment. E.D.C. is a delegate of Centre National de la Recherche Scientifique, in the frame of a French-German cooperation with Heidelberg University, Germany. E.D.C. thanks DFG via the SFB 544 (B14 project) and CNRS for financial support. R.H.S. and M.L. thanks DFG via the SFB 544 (B2 and B12 projects). T.M. thanks Prof. Thomas J.J. Müller for fruitful discussions during the $\mathrm{PhD}$ thesis work. The authors are grateful to Dr. Mourad Elhabiri, Strasbourg University for the direct metHb reduction experiment, Dr. Hervé Vezin for the residual data of cyclic voltammetry carried out in the experiments previously reported, ${ }^{11 \mathrm{~b}}$ and Prof. Louis Maes, Antwerp University for the primary cytotoxicity assays with the human MRC-5 cell line.

Supporting Information Available: Detailed experimental procedures, spectroscopic data, and elemental analyses for the preparation and the characterization of the new compounds 1-20, and cytotoxicity activities against human cells. This material is available free of charge via the Internet at http://pubs.acs.org.

(1) White, N. J. www.thelancet.com, 2010, 376, 2051-2052.

(2) Zarchin, S.; Krugliak, M.; Ginsburg, H. Biochem. Pharmacol. 1986, 35, 2435-2442.

(3) a) Abu-Bakar, N., Klonis, N., Hanssen, E., Chan, C, Tilley, L. J. Cell Sci. 2010, 123, 441450; b) Ncokazi, K. K.; Egan, T. J. Anal. Biochem. 2005, 338, 306-319; c) Cohen, S. N.; Phifer, K. O.; Yielding, K. L. Nature 1964, 202, 805-806; d) Egan, T. J. J. Inorg. Biochem. 2006, 100, 916-926; e) Egan, T. J. J. Inorg. Biochem. 2008, 102, 1288-1299.

(4) Dorn, A.; Stoffel, R.; Matile, H.; Bubendorf, A.; Ridley, R. Nature 1995, 374, 269-271.

(5) Loria, P.; Miller, S.; Foley, M.; Tilley, L. Biochem J. 1999, 339, 363-370.

(6) a) Atamna, H.; Ginsburg, H. J. Biol. Chem. 1995, 270, 24876-83; b) Ginsburg, H.; Famin, O. Zhang, J.; Krugliak, M. Biochem. Pharmacol. 1998, 56, 1305-1313.

(7) Vippagunta, S. R.; Dorn, A.; Ridley, R. G.; Vennerstrom, J. L. Biomed. Biochim. Acta 2000, 1475, 133-140.

(8) Hogg, T.; Nagarajan, K.; Herzberg, S.; Chen, L.; Shen, X.; Jiang, H.; Wecke, M.; Blohmke, C.; Hilgenfeld, R.; Schmidt, C. L. J. Biol. Chem. 2006, 281, 25425-25437.

(9) Monti, D.; Vodopivec, B.; Basilico, N.; Olliaro, P.; Taramelli, D. Biochemistry 1999, 38, 88588863.

(10) a) Schirmer, R. H.; Mueller, J. G.; Joachim, G.; Krauth-Siegel, R. L. Angew. Chem. Int. Ed. Engl. 1995, 34, 141-154; b) Krauth-Siegel, R. L.; Bauer, H.; Schirmer, R. H. Angew. Chem. Int. Ed. Engl. 2005, 44, 690-715.

(11) a) Biot, C.; Bauer, H.; Schirmer, R. H.; Davioud-Charvet, E. J. Med. Chem. 2004, 47, 5972-5983; b) Bauer, H.; Fritz-Wolf, K.; Winzer, A.; Kühner, S.; Little, S.; Yardley, V.; Vezin, H.; Palfey, B.; Schirmer, R. H.; DavioudCharvet, E. J. Am. Chem. Soc. 2006, 128, 
10784-10794; c) Morin, C.; Besset, T.; Moutet, J.-C.; Fayolle, M.; Brückner, M.; Limosin, D.; Becker, K.; Davioud-Charvet, E. Org. Biomol. Chem. 2008, 6, 2731-2742; d) Davioud-Charvet, E.; Lanfranchi, D. A. in Apicomplexan parasites - Molecular approaches toward targeted drug development (Eds.: K. Becker, P. M. Selzer), Drug Discovery in Infectious Diseases (volume 2), 2011, Wiley-VCH, Weinheim.

(12) a) Davioud-Charvet, E.; Delarue, S.; Biot, C.; Schwöbel, B.; Böhme, C. C.; Müssigbrodt, A.; Maes, L.; Sergheraert, C.; Grellier, P. Schirmer, R. H.; Becker, K. J. Med. Chem. 2001, 44, 42684276; b) Friebolin, W.; Jannack, B.; Wenzel, N.; Furrer, J.; Oeser, T.; Sanchez, C. P.; Lanzer, M.; Yardley, V.; Becker, K.; Davioud-Charvet, E. $J$. Med. Chem. 2008, 51, 1260-1277.

(13) a) Subba-Rao, R. V., Alexander, M. Appl. Environ. Microbiol. 1985, 49, 509-516.; b) Segrestaa, J.; Verite, P.; Estour, F.; Menager, S.; Lafont, O. Chem. Pharm. Bull. 2002, 50, 744748.

(14) a) Jaffé, E. R.; Neurmann, G. Nature. 1964, 202, 607-608; b) Beutler, E.; Baluda, M. C. Blood. 1963, 22, 323-233.

(15) Kochi, J. K.; Anderson, J. M. J. Am. Chem. Soc. 1970, 92, 1651-1659.

(16) Yamazaki, S. Org. Lett. 1999, 1, 2129-2132.

(17) Evans, P. A.; Brandt, T. A. J. Org. Chem. 1997, $62,5321-5326$

(18) O'Brien, J.; Wilson, I.; Orton, T.; Pognan, F. Eur. J. Biochem. 2000, 267, 5421-5426.

(19) Desjardins, R. E.; Canfield, C. J.; Haynes, J. D.; Chulay, J. D. Antimicrob. Agents Chemother. 1979, 16, 710-718.

(20) a) Hanoulle, X., Wieruszeski, J. M., RousselotPailley, P., Landrieu, I., Locht, C., Lippens, G., Baulard, A. R. J. Antimicrob. Chemother. 2006, 58, 768-772; b) Hanoulle, X., Wieruszeski, J. M., Rousselot-Pailley, P., Landrieu, I., Baulard, A. R., Lippens, G. Biochem. Biophys. Res. Commun. 2005, 331, 452-458.

(21) Hünig, S.; Bau, R.; Kemmer, M.; Meixner, H.; Metzenthin, T.; Peters, K.; Sinzger, K.; Gulbis, J. Eur. J. Org. Chem. 1998, 335-348.

(22) Kitz, R.; Wilson, I. B. J. Biol. Chem. 1962, 237, 3245-3249.

(23) Gulino, D. ; Pham, Q. T. ; Golé, J. ; Pascault, J. P. In: Anionic Polymerization. November 30, 1981, 307-326. ACS Symposium Series, Vol. 166, Chapter 20, pp 307-326, American Chemical Society, Eds.

(24) Jain, M.; Vangapandu, S.; Sachdeva, S.; Singh, S.; Singh, P. P.; Jena, G. B.; Tikoo, K.; Ramarao, P.; Kaul, C. L.; Jain, R. J. Med. Chem. 2004, 47, 285-287.

(25) Cappellini, M. D.; Fiorelli, G. Lancet 2008, 371, 64-74.

(26) Ginsburg, H.; Atamna, H.; Shalmiev, G.; Kanaani, J.; Krugliak, M. Parasitology 1996, $113,7-18$
(27) a) Zhang, Y. A.; Hempelmann, E.; Schirmer, R. H. Biochem. Pharmacol. 1988, 37, 855-860; b) Zhang, Y.; König, I.; Schirmer, R. H. Biochem. Pharmacol. 1988, 37, 861-865.

(28) Lüersen, K.; Walter, R. D.; Müller, S. Biochem. J. 2000, 346, 545-552.

(29) Cappadoro, M.; Giribaldi, G.; O'Brien, E.; Turrini, F.; Mannu, F.; Ulliers, D.; Simula, G.; Luzzatto, L.; Arese, P. Blood 1998, 92, 25272534.

(30) Gallo, V., Schwarzer, E., Rahlfs, S., Schirmer, R. H., van Zwieten, R., Roos, D., Arese, P., Becker, K. PLoS One 2009, 4:e7303.

(31) Baird J. K.; Surjadjaja, C. Trends Parasitol. 2011, 27, 11-16.

(32) a) Färber, P. M.; Arscott, L. D.; Williams Jr, C. H.; Becker, K.; Schirmer, R. H. FEBS Lett. 1998 , 422, 311-314; b) Schirmer, M.; Scheiwein, M.; Gromer, S.; Becker, K.; Schirmer, R. H. in Flavins and Flavoproteins 1999 (Eds: S. Ghisla, P. Kroneck, P. Macheroux, H. Sund), Rudolf Weber, Agency for Scientific Publications, 1999, Berlin, pp. 857-862; c) Kasozi, D., Gromer, S., Adler, H., Zocher, K., Rahlfs, S., Wittlin, S., Fritz-Wolf, K., Schirmer, R. H., Becker, K. Redox Rep. 2011, in press.

(33) Davioud-Charvet, E.; Müller, T.; Bauer, H.; Schirmer. R. H. Patent EP 08290278.4 (March 26, 2008). PCT/EP2009/053483 (25-03-2009).

(34) Cohen, M. S.; Chai, Y.; Britigan, B. E.; McKenna, W.; Adams, J.; Svendsen, T.; Bean, K.; Hassett, D. J.; Sparling, P. F. Antimicrob Agents Chemother. 1987, 31, 1507-1513.

(35) a) Anstey, N. M.; Hassanali, M. Y.; Mlalasi, J.; Manyenga, D.; Mwaikambo, E. D. Trans. R Soc. Trop. Med. Hyg. 1996, 90, 147-151; b) Srivastava, S., Alhomida, A. S., Siddiqi, N. J. In Vivo 2000, 14, 547-550.

(36) Brabin, B. J., Eggelte, T. A., Parise, M., Verhoeff, F. Drug Saf. 2004, 27, 633-48.

(37) Vale, N.; Moreira, R.; Gomes, P. Eur. J. Med. Chem. 2009, 44, 937-953.

(38) Liu, H.; Walker, L. A.; Nanayakkara, N. P.; Doerksen, R. J. J. Am. Chem. Soc. 2011, 133, 1172-75.

(39) Trager, W. ; Jensen, J. B. Science 1976, 193 , 673-675.

(40) Nordhoff, A.; Bucheler, U. S.; Werner, D.; Schirmer, R. H. Biochemistry 1993, 32, 40604066.

(41) Peters, W.; Robinson, B. L. Handbook of Animal Models of Infection. Academic Press, London 1999; pp. 756-771

(42) Pasvol, G.; Wilson, R. J, Smalley, M. E.; Brown, J. Ann. Trop. Med. Parasitol. 1978, 72, 87-88

(43) Lambros C.; Vanderberg J. P. J. Parasitol. 1979, 65, 418-420.

(44) Uno, H. J. Org. Chem. 1986, 51, 350-358. 


\section{Graphic entry for the Table of Contents (TOC)}

A Glutathione Reductase-Catalyzed Cascade of Redox Reactions to Bioactivate Potent Antimalarial 1,4-Naphthoquinones - A New Strategy to Combat Malarial Parasites

Tobias Müller, Laure Johann, Beate Jannack, Margit Brückner, Don Antoine Lanfranchi, Holger Bauer, Cecilia Sanchez, Vanessa Yardley, Christiane Deregnaucourt, Joseph Schrével, Michael Lanzer, Heiner Schirmer, Elisabeth DavioudCharvet $^{*}$ 